\title{
PALAEO
}

ELSEVIER

Palaeogeography, Palaeoclimatology, Palaeoecology 145 (1999) 95-117

\section{Evidence for a steeper Eemian than Holocene sea surface temperature gradient between Arctic and sub-Arctic regions}

\author{
Henning A. Bauch ${ }^{\text {a,* }}$, Helmut Erlenkeuser ${ }^{\mathrm{b}}$, Kirsten Fahl ${ }^{\mathrm{c}}$, Robert F. Spielhagen ${ }^{\mathrm{a}}$, \\ Mara S. Weinelt ${ }^{\mathrm{d}}$, Harald Andruleit ${ }^{\mathrm{e}}$, Rüdiger Henrich ${ }^{\mathrm{f}}$ \\ ${ }^{a}$ GEOMAR, Zentrum für marine Geowissenschaften, Wischhofstrasse 1-3, 24148 Kiel, Germany \\ ${ }^{b}$ Leibniz Labor, Christian-Albrechts-Universität, Max-Eyth-Strasse 11, 24098 Kiel, Germany \\ ${ }^{c}$ Alfred-Wegener-Institut für Polar- und Meeresforschung, Columbusstrasse, 27515 Bremerhaven, Germany \\ ${ }^{d}$ Institut für Geologie and Paläontologie, Christian-Albrechts-Universität, Olshausenstrasse 40-50, 24098 Kiel, Germany \\ ${ }^{e}$ Bundesanstalt für Geowissenschaften und Rohstoffe, P.O. Box 510153, 30631 Hanover, Germany \\ ${ }^{f}$ Fachbereich Geowissenschaften, Universität Bremen, Postfach 330440, 28334 Bremen, Germany
}

Received 8 July 1997; revised version received 2 June 1998; accepted 23 June 1998

\begin{abstract}
Sediment proxy data from the Norwegian, Greenland, and Iceland seas (Nordic seas) are presented to evaluate surface water temperature (SST) differences between Holocene and Eemian times and to deduce from these data the particular mode of surface water circulation. Records from planktic foraminiferal assemblages, $\mathrm{CaCO}_{3}$ content, oxygen isotopes of foraminifera, and iceberg-rafted debris form the main basis of interpretation. All results indicate for the Eemian comparatively cooler northern Nordic seas than for the Holocene due to a reduction in the northwardly flow of Atlantic surface water towards Fram Strait and the Arctic Ocean. Therefore, the cold polar water flow from the Arctic Ocean was less influencial in the southwestern Nordic seas during this time. As can be further deduced from the Eemian data, slightly higher Eemian SSTs are interpreted for the western Iceland Sea compared to the Norwegian Sea (ca. south of $70^{\circ} \mathrm{N}$ ). This Eemian situation is in contrast to the Holocene when the main mass of warmest Atlantic surface water flows along the Norwegian continental margin northwards and into the Arctic Ocean. Thus, a moderate northwardly decrease in SST is observed in the eastern Nordic seas for this time, causing a meridional transfer in ocean heat. Due to this distribution in SSTs the Holocene is dominated by a meridional circulation pattern. The interpretation of the Eemian data imply a dominantly zonal surface water circulation with a steep meridional gradient in SSTs. () 1999 Elsevier Science B.V. All rights reserved.
\end{abstract}

Keywords: Eemian; Holocene; climate; foraminifera; sea surface temperature; surface water circulation; Nordic seas; Arctic Ocean

\section{Introduction}

Terrestrial evidence from ice cores and floral records reveal that during the past $140 \mathrm{ka}$ only

\footnotetext{
* Corresponding author. Tel.: +49 431600 2856; Fax: +49 431 600 2941; E-mail: hbauch@geomar.de
}

the last interglaciation, the Eemian (marine oxygen isotope stage 5e), had climatic conditions which in many respect appear comparable to the Holocene (e.g., Woillard, 1978), for example, indicating for western Europe slightly higher temperatures for midto higher latitudes then (Velichko et al., 1984; Guiot et al., 1993). During the past 20 years many studies 
have dealt with the paleoceanography of the Iceland, Greenland, and Norwegian (Nordic) seas. They were based on calcium carbonate, stable isotope, and micropalaeontological data that, on a broader scale, greatly enhanced the knowledge about major glacial/interglacial variations during the late Quaternary oceanographical evolution of the Nordic Seas (e.g., Kellogg, 1980; Belanger, 1982; CLIMAP, 1984; Labeyrie et al., 1987; Henrich et al., 1989). Although more interest in marine Eemian records at northern latitudes was initiated recently (e.g., Keigwin et al., 1994; McManus et al., 1994; Bodén and Backman, 1996), profound palaeoceanographic reconstructions as they have been suggested for the past 20 ka (e.g., Lehman et al., 1991; Sarnthein et al., 1995) are still lacking for the last interglaciation in the Nordic seas despite some first attempts (Kellogg, 1980; Cortijo et al., 1994; Bauch, 1996; Fronval and Jansen, 1996)

Studying sediments from the Nordic seas, Kellogg (1980) was the first to note that Holocene-like surface water conditions occurred during marine oxygen isotope stage 5e (MIS 5e). His conclusions were based on planktic foraminiferal data and the deduced pattern of surface water circulation did not differ significantly from the Holocene situation. Haake and Pflaumann (1989) recognized development of 'modern-like' surface water circulation and bottom water formation during the last interglaciation in the later part of MIS 5e. Although their study was based on cores from a very limited area of the NE Norwegian Sea recent investigations of the last interglaciation confirm the previous conclusion that the planktic foraminiferal assemblage over the southern part of the Nordic seas is in general quite comparable to the Holocene (Bauch et al., 1996; Fronval and Jansen, 1996).

All species of planktic foraminifera that occur in late Pleistocene or Holocene sediments of the higher latitudes can be assigned to either a polar or a subpolar assemblage (Kipp, 1976; Hemleben et al., 1989). In the Nordic seas these assemblages correspond to either a glacial or an interglacial group. Neogloboquadrina pachyderma sinistral (sin.) is the only true polar species in this area. This species has been related to cold water masses $\left(<10^{\circ} \mathrm{C}\right)$ and makes up $>95 \%$ of the assemblage in surface waters below $5^{\circ} \mathrm{C}$ (Bé and Tolderlund, 1971). In comparison, the subpolar group is predominantly made up of Tur- borotalita quinqueloba (Bauch, 1994, 1996). Species of temperate or subtropical provenance occur occasionally (Kellogg, 1984; Haake and Pflaumann, 1989). These latter species are sparse and mostly restricted to the Eemian and then only to the southeastern part of the Nordic seas where the influence of North Atlantic surface water is strongest today and was also presumably strong during the past interglaciation (Kellogg, 1980).

Estimates of past sea surface temperatures (SST) derived from foraminiferal assemblages have long been a common tool to express glacial-interglacial contrasts (CLIMAP, 1981, 1984). The same methods have been transferred to other planktic proxy data (e.g., Koç-Karpuz and Jansen, 1992). However, terrestrial and marine records (e.g., Stute et al., 1995; Bard et al., 1997) now indicate that for instance during the last glacial maximum (LGM) temperatures in the tropics were much lower than suggested by the CLIMAP studies based on foraminifera, essentially leaving doubt on the methodological validity of foraminiferal-derived SSTs at these latitudes. These problems should be kept in mind when evaluating environmental parameter from foraminiferal data of the Nordic seas, where very complex gradients in temperature and salinity shape the upper hydrography today and presumably also in the past.

The intent of this study is to demonstrate the usefulness of various important climate proxy tools for regional paleoceanography, and to show that by using a multiproxy approach, surface water conditions in the Nordic seas during the last interglaciation were in a qualitative respect quite dissimilar from those of Holocene times.

\section{Oceanographic setting, material, and methods}

Today, the surface water regime of the Nordic seas is characterized by a threefold subdivision (Swift, 1986). Salinity and temperatures decrease towards the north and west. Relatively warm high salinity Atlantic surface water $\left(6-11^{\circ} \mathrm{C},>35 \%\right.$ ) flows as Norwegian Current (NC) along the Norwegian and Svalbard shelf margins northward into the eastern Arctic Ocean basin. This forms the Atlantic Domain (Fig. 1). The western part of the Nordic seas is marked by the outflow of the relatively cold and at 


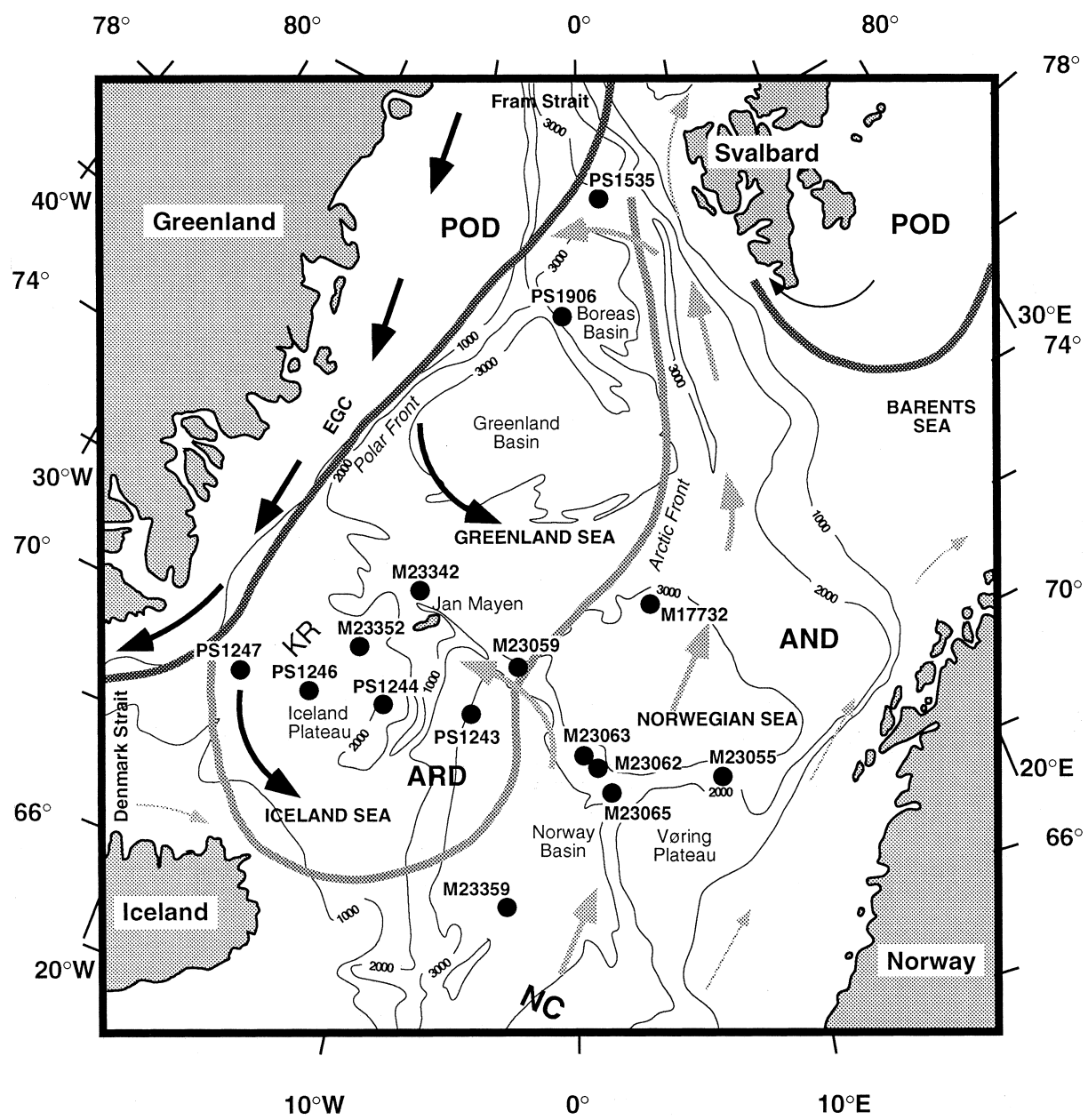

Fig. 1. Simplified modern surface water circulation of the Nordic seas and its major oceanographic regimes (Swift, 1986); POD (Polar Domain), ARD (Arctic Domain), AND (Atlantic Domain). Grey and black arrows denote warmer and cooler surface currents, respectively. $E G C$ (East Greenland Current), NC (Norwegian Current); KR (Kolbeinsey Ridge).

the surface low salinity water $\left(<0^{\circ} \mathrm{C},<34.4 \%\right.$ o $)$ of the East Greenland Current (EGC) from the Arctic Ocean. The EGC flows from the Nordic seas through Denmark Strait into the North Atlantic making up the Polar Domain. The Polar and Atlantic Domain are separated by mixed water termed the Arctic Domain. The Arctic Domain is the main site of deep water formation in the Nordic seas, and has two distinct oceanographic fronts on either side. Due to the northerly flow of the Atlantic water the Nordic seas display a S-N alignment of these fronts with a moderate temperature decrease on the eastern side but with a steep temperature gradient towards Greenland (Dietrich, 1969; Swift, 1986).
The data presented here derive from long gravity cores and trigger box cores that were collected from the Nordic seas during several cruises over the past decade (Fig. 1, Table 1). The stratigraphical framework of these cores is mainly based on oxygen stable isotope records measured on the planktic foraminifera $N$. pachyderma sin. Benthic stable isotope analyses which were performed on Cibicidoides wuellerstorfi and Oridorsalis umbonatus are corrected by $+0.64 \%$ ond $+0.36 \%$, respectively, to account for their individual species-dependent departure from isotopic equilibrium (Duplessy et al., 1988). All isotope measurements were carried out on multi-specimen samples using a fully automated 
Table 1

List of investigated cores

\begin{tabular}{llll}
\hline Site & \multicolumn{2}{l}{ Geographical position } & \multirow{2}{l}{$\begin{array}{l}\text { Water depth } \\
(\mathrm{m})\end{array}$} \\
\cline { 2 - 3 } & latitude $(\mathrm{N})$ & longitude & \\
\hline PS1243 & $69^{\circ} 22.3^{\prime}$ & $06^{\circ} 32.1^{\prime} \mathrm{W}$ & 2710 \\
PS1244 & $69^{\circ} 22.0^{\prime}$ & $08^{\circ} 40.0^{\prime} \mathrm{W}$ & 2162 \\
PS1246 & $69^{\circ} 23.6^{\prime}$ & $12^{\circ} 52.1^{\prime} \mathrm{W}$ & 1902 \\
PS1247 & $69^{\circ} 29.5^{\prime}$ & $17^{\circ} 7.0^{\prime} \mathrm{W}$ & 1400 \\
PS1535 & $78^{\circ} 44.8^{\prime}$ & $01^{\circ} 47.4^{\prime} \mathrm{E}$ & 2557 \\
PS1906 & $76^{\circ} 50.1^{\prime}$ & $02^{\circ} 09.1^{\prime} \mathrm{W}$ & 2939 \\
M17732 & $71^{\circ} 36.8^{\prime}$ & $04^{\circ} 12.8^{\prime} \mathrm{E}$ & 3103 \\
M23055 & $68^{\circ} 25.4^{\prime}$ & $04^{\circ} 01.3^{\prime} \mathrm{E}$ & 2311 \\
M23059 & $70^{\circ} 18.3^{\prime}$ & $03^{\circ} 07.4^{\prime} \mathrm{W}$ & 2281 \\
M23062 & $68^{\circ} 43.7^{\prime}$ & $00^{\circ} 10.1^{\prime} \mathrm{E}$ & 2244 \\
M23063 & $68^{\circ} 45.0^{\prime}$ & $00^{\circ} 00.0^{\prime} \mathrm{W}$ & 2299 \\
M23065 & $68^{\circ} 29.7^{\prime}$ & $00^{\circ} 49.1^{\prime} \mathrm{E}$ & 2802 \\
M23342 & $71^{\circ} 38.2^{\prime}$ & $08^{\circ} 38.2^{\prime} \mathrm{W}$ & 1974 \\
M23352 & $70^{\circ} 00.4^{\prime}$ & $12^{\circ} 25.8^{\prime} \mathrm{W}$ & 1819 \\
M23359 & $65^{\circ} 31.7^{\prime}$ & $04^{\circ} 09.6^{\prime} \mathrm{W}$ & 2820 \\
\hline
\end{tabular}

Finnigan MAT 251 mass spectrometer (Leibniz Laboratory at Kiel University). Where radiocarbon measurements have been performed on $N$. pachyderma sin. for age determination, all marine datings are reservoir corrected by subtracting 400 years.

Sample intervals are $5-10 \mathrm{~cm}$ for the long cores and $2-5 \mathrm{~cm}$ for the box cores and Holocene sections. Some Eemian sections have been sampled at 1 and $2 \mathrm{~cm}$ intervals, although in most cases the Eemian interval was sampled at wider spacings than the Holocene. But the large number of investigated cores and the fact that certain cores from key positions were also sampled at closer intervals in the Eemian sections will ensure a reliable picture of the general trends. Furthermore, care was taken to sample the central part of the Eemian interglacial section, which can be usually recognized by its distinct sediment colour due to high carbonate content.

In studying the planktic foraminiferal fauna, the $125-250$ and $250-500 \mu \mathrm{m}$ size-fraction were examined separately to make better estimates of abundance of the relatively small subpolar species $T$. quinqueloba and other rarely occurring species that are larger than $250 \mu \mathrm{m}$ (Bauch, 1992, 1994). The faunal results are expressed as test concentrations (specimens per gram of dry sediment) and as relative abundances (\%).

From some Holocene and Eemian samples the content of long-chain alkenones were measured in order to (1) derive SSTs from the alkenone $U_{37}^{K^{\prime}}$ and (2) to compare these SSTs with the overall pattern deduced from the foraminiferal assemblage data. The alkenone composition was analysed by GC/MS which consists of a gas chromatograph (HP 5890 , column $30 \mathrm{~m} \times 0.25 \mathrm{~mm}$; film thickness 0.25 $\mu \mathrm{m}$; liquid phase: HP 5) and a mass spectrometer (MSD, HP 5972, 70 eV electron-impact-ionisation, Scan $50-650 \mathrm{~m} / \mathrm{z}, 1 \mathrm{scan} / \mathrm{s}$, ion source temperature $\left.175^{\circ} \mathrm{C}\right)$. For further details concerning extraction and saponification see Fahl and Stein (1998). The unsaturation index $U_{37}^{K^{\prime}}$ was calculated according to three different calibration methods (Prahl and Wakeham, 1987; Sikes and Volkman, 1993; Rosell-Melé et al., 1995; Table 2). Due to the comparability of the investigation areas, the calibration published by Rosell-Melé et al. (1995) was used for our interpretation. We want to point out that the records of long-chain unsaturated alkenones in high-latitude, low temperature areas are difficult to interpret and often discussed (e.g., Conte and Eglinton, 1993). Thus, the results should be assessed as an estimation which, however, appears to be permissible in combination with the other data.

To be sure that we would compare core sections which were deposited under similar climatic conditions (Bauch et al., 1996), the cessation and recurrence of the iceberg-rafted debris (IRD) in relation to the Holocene and Eemian intervals were carefully noted. This approach allows a defined separation of those core section which were deposited during the time of major deglaciation (Termination), i.e., marked by input of IRD and freshwater from melting icebergs, from the ensuing core sections which are characterized by low or no IRD content but high abundance of warm-water indicating foraminiferal species (Bauch et al., 1996).

\section{Palaeoceanographic proxy records}

\subsection{Conditions during the last two glacial-interglacial cycles}

Fig. 2 provides a general overview of changing conditions during the last two glacial-interglacial cycles, showing the distribution of various proxies 
Table 2

Results of $U_{37}^{K^{\prime}}$ analyses and calculated SST-estimates

\begin{tabular}{|c|c|c|c|c|c|}
\hline $\begin{array}{l}\text { Core } \\
(\mathrm{cm})\end{array}$ & $U_{37}^{K^{\prime}}$ & $\begin{array}{l}T\left({ }^{\circ} \mathrm{C}\right) \\
\text { (a) }\end{array}$ & $\begin{array}{l}T\left({ }^{\circ} \mathrm{C}\right) \\
\text { (b) }\end{array}$ & $\begin{array}{l}T\left({ }^{\circ} \mathrm{C}\right) \\
\text { (c) }\end{array}$ & $\begin{array}{l}T\left({ }^{\circ} \mathrm{C}\right) \\
\text { (d) }\end{array}$ \\
\hline \multicolumn{6}{|c|}{ M23352 } \\
\hline 2 & 0.35 & 11.5 & 12.3 & 8.5 & \\
\hline 7 & 0.38 & 12.3 & 13.2 & 9.7 & \\
\hline 12 & 0.33 & 11.0 & 11.9 & 8 & \\
\hline 15 & 0.37 & 12.1 & 12.9 & 9.4 & \\
\hline 18 & 0.34 & 11.4 & 12.2 & 8.4 & \\
\hline 21 & 0.37 & 11.9 & 12.8 & 9.2 & 8.8 \\
\hline 30 & n.d. & n.d. & n.d. & n.d. & \\
\hline 34 & n.d. & n.d. & n.d. & n.d. & \\
\hline 219 & n.d. & n.d. & n.d. & n.d. & \\
\hline 222 & n.d. & n.d. & n.d. & n.d. & \\
\hline 225 & n.d. & n.d. & n.d. & n.d. & \\
\hline 227 & 0.39 & 12.6 & 13.4 & 10 & \\
\hline 228 & 0.44 & 13.9 & 14.7 & 11.7 & \\
\hline 232 & 0.37 & 11.9 & 12.7 & 9.1 & \\
\hline 238 & 0.39 & 12.6 & 13.4 & 10 & \\
\hline 241 & 0.45 & 14.0 & 14.8 & 12 & 10.5 \\
\hline 244 & n.d. & n.d. & n.d. & n.d. & \\
\hline 250 & n.d. & n.d. & n.d. & n.d. & \\
\hline 260 & n.d. & n.d. & n.d. & n.d. & \\
\hline \multicolumn{6}{|c|}{ PS1243 } \\
\hline 6 & 0.45 & 14.1 & 14.7 & 11.9 & \\
\hline 10 & 0.42 & 13.2 & 13.8 & 10.9 & \\
\hline 14 & 0.42 & 13.2 & 13.9 & 10.9 & \\
\hline 17 & 0.43 & 13.5 & 14.1 & 11.2 & \\
\hline 18 & 0.42 & 13.2 & 13.9 & 10.9 & \\
\hline 20 & 0.45 & 14.1 & 14.6 & 11.9 & \\
\hline 22 & 0.46 & 14.3 & 14.9 & 12.2 & 11.4 \\
\hline 210 & 0.36 & 11.6 & 12.5 & 8.9 & \\
\hline 216 & 0.38 & 12.2 & 13 & 9.6 & \\
\hline 219 & 0.37 & 11.9 & 12.8 & 9.2 & \\
\hline 225 & 0.38 & 12.2 & 12.9 & 9.6 & \\
\hline 230 & 0.39 & 12.4 & 13.2 & 9.9 & 9.2 \\
\hline \multicolumn{6}{|c|}{ M17732 } \\
\hline 30 & 0.49 & 15.0 & 15.8 & 13.3 & \\
\hline 50 & 0.54 & 16.2 & 17 & 14.9 & 14.1 \\
\hline 355 & 0.43 & 13.4 & 14.2 & 11.1 & \\
\hline 370 & 0.46 & 14.2 & 15 & 12.2 & \\
\hline 395 & 0.43 & 13.6 & 14.4 & 11.3 & 11.5 \\
\hline
\end{tabular}

(a) After Prahl and Wakeham (1987); (b) after Sikes and Volkman (1993); (c) after Rosell-Melé et al. (1995); (d) average $T$ for the Holocene and Eemian samples of (c); n.d. = not detected.

in a core from the eastern Nordic seas. The relative records of IRD and $\mathrm{CaCO}_{3}$ indicate variable input of terrigenous material from melting icebergs on one hand and pelagic carbonate productivity on the other. The results demonstrate that similar cli- mate boundary conditions existed during the late Holocene and the upper part of MIS 5e and also agree in this respect with previously published accumulation rates of $\mathrm{CaCO}_{3}$ and IRD for this area (Baumann et al., 1995). As can be deduced from the intervals with low IRD and high $\mathrm{CaCO}_{3}$ contents in relation to the benthic and $\delta^{18} \mathrm{O}$ record, only these sections reflect full-marine interglacial conditions and times of lowest global ice volume. It becomes further apparent that Termination II penetrates far into the interval of MIS 5e which is characterized by rather low $\delta^{18} \mathrm{O}$ values and, thus, is not just restricted to the part of the $\delta^{18} \mathrm{O}$ slope which follows MIS 6. This feature (see also Fig. 3a) appears to be typical for Eemian sections in cores from the Norwegian continental margin (Vogelsang, 1990; Baumann et al., 1995; Fronval and Jansen, 1996) and is probably due to enhanced deposition of particularly fine-grained clastic sediments discharged from melting icebergs during Termination II in this area (Henrich et al., 1989). This discharge obviously led to relatively high average sedimentation rates in Termination II compared with the later part of MIS 5e when deposition of coarser-grained pelagic components (e.g. foraminifera) became more dominant. Therefore, much of the variability in the planktic $\delta^{18} \mathrm{O}$ records which is observed in Termination II of cores M23055 and M23065 can be attributed to rather short-termed and highly variable seasonal meltwater fluxes rather than being the result of longer-termed climatic changes. Due to these obvious problems associated with the particular sedimentation dynamics in this area throughout MIS 5e, we refrained from constructing an age model for this interval, even more so because an age model is not essential to the outcome of this study.

For the following comparison of Eemian and Holocene data, it is important to note that the carbonate record shows highest values together with low IRD and lowest benthic oxygen isotope values, i.e., smallest global ice volume. Due to the lack of IRD we infer that freshwater from melting icebergs could neither affect the planktic $\delta^{18} \mathrm{O}$ records nor the foraminiferal habitat by lowering surface salinity during this time. Furthermore, because these intervals which are marked by warm-water indicating planktic foraminifera also coincide with low global ice volume during the Holocene and the Eemian re- 

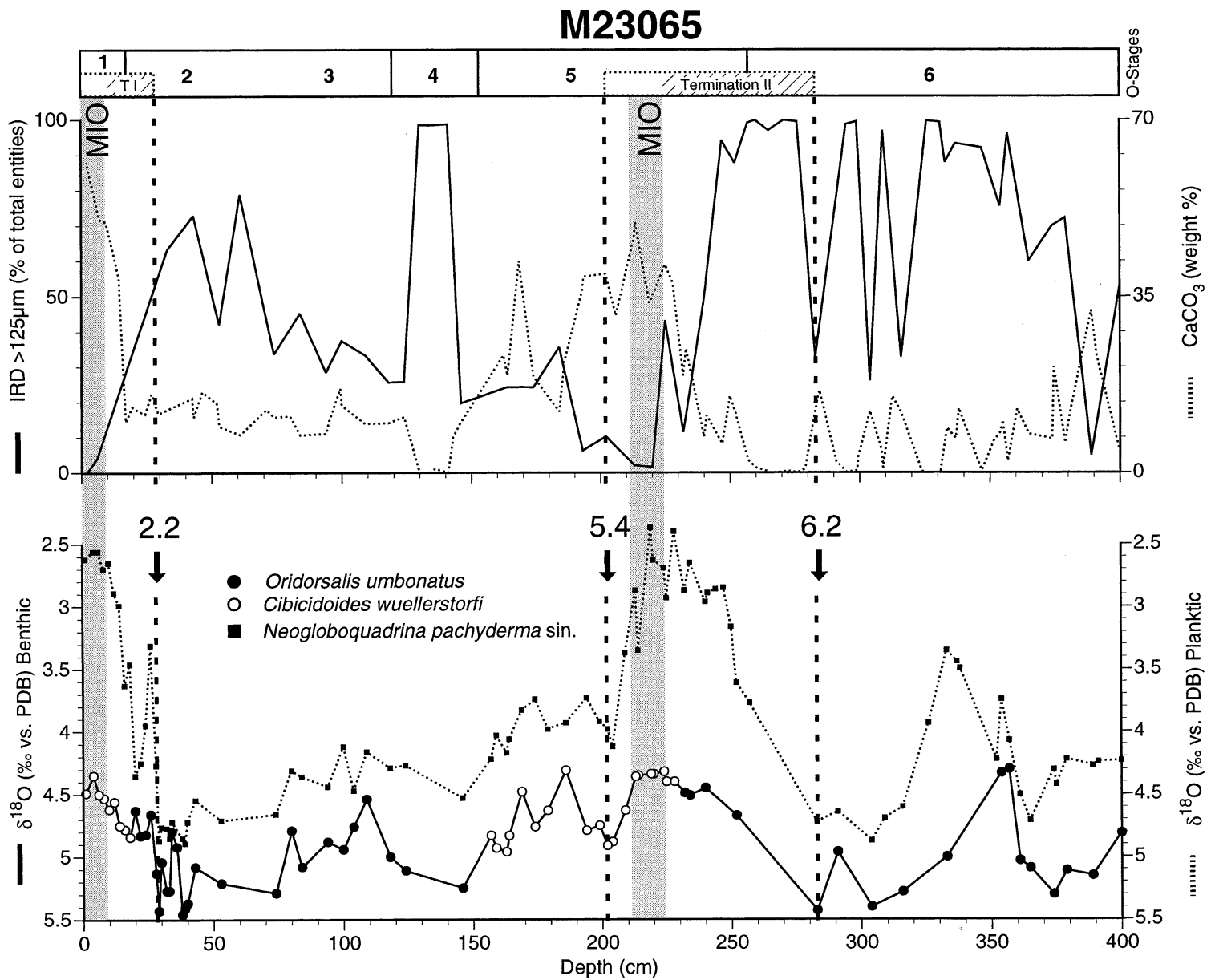

Fig. 2. Comparison of $\delta^{18} \mathrm{O}$ records of the benthic species Oridorsalis umbonatus and Cibicidoides wuellerstorfi and the planktic foraminifera Neogloboquadrina sin. with IRD (\% of total entities) and $\mathrm{CaCO}_{3}$ (\% of total weight of sample) over the past two glacial/interglacial cycles. Shaded bars mark the marine interglacial optimum (MIO) within the Eemian (MIS 5e) and Holocene intervals as interpreted from the lowest observed IRD content (note the difference in sample intervals between the upper and lower graph, which may explain some of the slight offsets observed between the various records). Arrows indicate major oxygen isotope events (Martinson et al., 1987), which frame the two interglaciations (figure is redrawn from Bauch et al., 1996).

spectively (Fronval and Jansen, 1996), we will refer to each of these as the marine interglacial optimum (MIO) proper. Therefore, only the data from the MIOs are used for comparing Holocene with Eemian sea surface conditions (Bauch et al., 1996).

\subsection{Composition of Eemian and Holocene faunal assemblages}

Both Eemian and Holocene faunal records (Fig. 3a, b) show a decrease in the relative abundance of the polar water species $N$. pachyderma sin. towards the end

Fig. 3. Species distribution of the Eemian (a) and Holocene (b) intervals in comparison with planktic $\delta^{18} \mathrm{O}$ and IRD. Shaded vertical bars indicate the marine interglacial optimum $(M I O)$ which is interpreted on the basis of low abundance $(\%)$ of the polar species $N$. pachyderma sin. and none or lowest concentrations of iceberg-rafted debris (IRD). Subpolar species concentrations per gram of sediment are shown on different scales (number in parentheses behind these species names refer to the top scale of the vertical axis on the right hand side). $V A=$ Vedde Ash. 

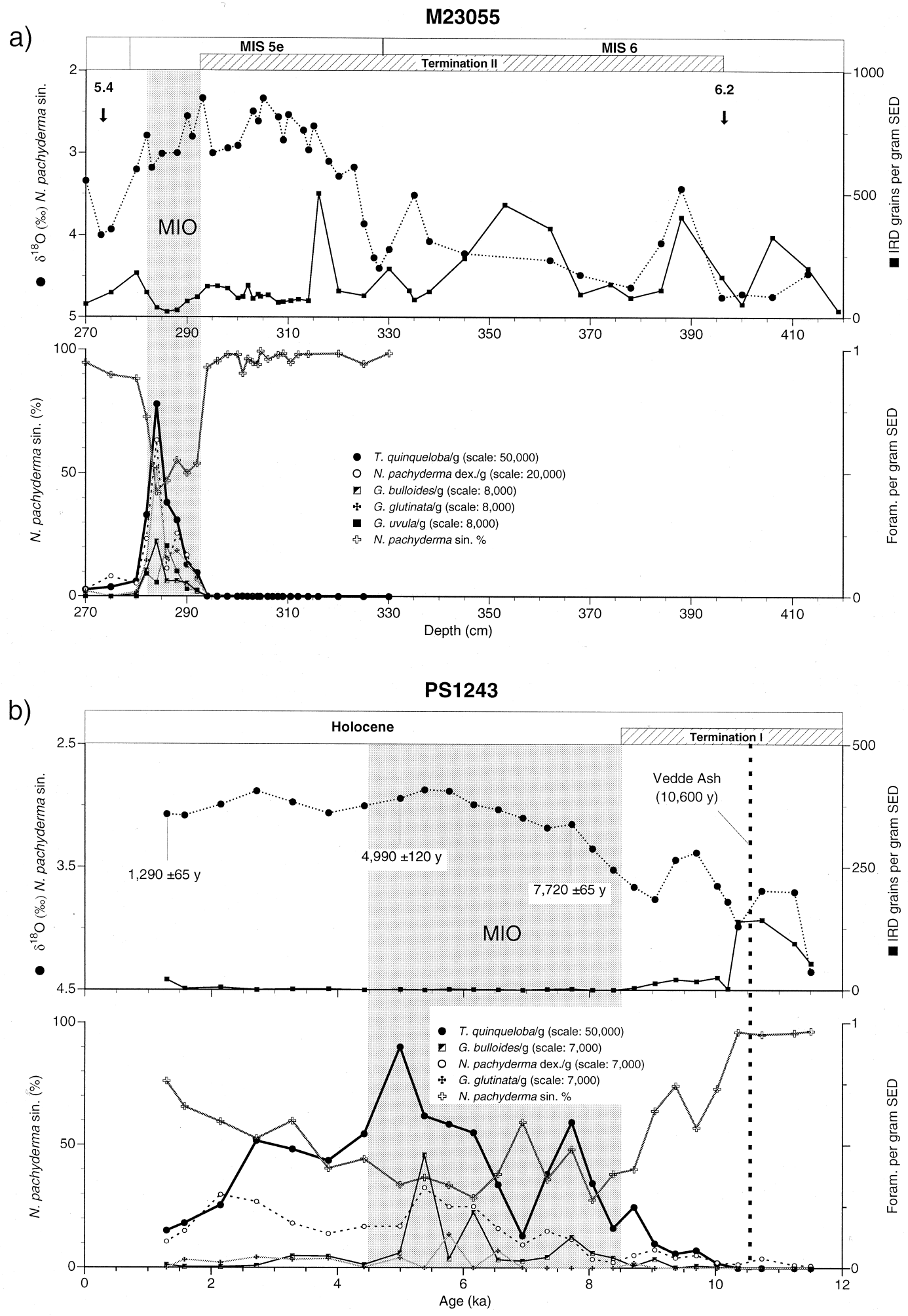
of the terminations. The highest abundances of interglacial (subpolar) species are always found in the IRD-free core sections. Of the subpolar foraminifera in core M23055 T. quinqueloba totals $\sim 40 \%$ during the Eemian and is by far the dominant species. In the Holocene, the main phase of high subpolar abundances falls between $8.5-4.5 \mathrm{ka}\left({ }^{14} \mathrm{C}\right)$; this time interval covers the Atlantic chronozone during which highest Holocene temperatures were recorded globally as well as regionally (COHMAP Members, 1988; Nesje and Kvamme, 1991). Turborotalita quinqueloba dominates the subpolar fauna and makes up to $70 \%$ of the total assemblage, whereas the other subpolar species do not exceed 10\% altogether. This westward decline of subpolar species other than $T$. quinqueloba is typical, indicating the wider range of the latter in terms of water mass adaptation. Therefore, the fauna of the Holocene and Eemian sections is more diverse in the cores from the east, i.e., the Vøring Plateau and further south, beneath the main flow of Atlantic water, than to the west and north (see also Kellogg, 1980). Globigerina bulloides, for example, may be strictly regarded an Atlantic water type, because on the Iceland Plateau (west of core PS1243) and outside the Atlantic Domain this species is basically not encountered in both, surface and interglacial sediments (Johannessen et al., 1994; Bauch, 1997). In contrast, Eemian core sections from the southeast contain, besides the shown species, also very low concentrations of, e.g., Globorotalia inflata, Glr. scitula, Glr. truncatulinoides (Bauch, 1993). These species are not usually considered subpolar, but belong to typical subtropical and/or temperate assemblages (Kipp, 1976). Their maximum abundances usually coincide well with that of all other subpolar species (Bauch, 1993).

\subsection{Holocene record}

In Fig. 4 the relative distribution of the most abundant subpolar and polar species in the Nordic seas,
T. quinqueloba and N. pachyderma sin. are given in comparison with the $\delta^{18} \mathrm{O}$ record for the time period since the LGM. MIS 2 is clearly confirmed in all of these cores not only by high glacial $\delta^{18} \mathrm{O}$ values but also by the identification of the benthic foraminifera Siphotextularia rolshauseni (Bauch, 1993) which in the Nordic seas exhibits a renowned biostratigraphic event throughout MIS 2 (Nees and Struck, 1994; Struck, 1995). In nearly all cores, the abundance record of $T$. quinqueloba, which, in the cooler regions, is almost inversely related to $N$. pachyderma sin. reveals a similar pattern after MIS 2: during Termination I, there is a notable initial increase of this species. But it is only after the deglaciation had ceased that the abundance rises to peak values within the Holocene. In core PS1243 the highest abundances of T. quinqueloba fall between 8-5 ka (see Fig. 3b). This is clearly above the Younger Dryas, which in this region is commonly identified by the stratigraphic position of the Vedde Ash (Mangerud et al., 1984), and above the final deposition of IRD. Ages between 9-6 ka for the main occurrence of subpolar species and about $8.5 \mathrm{ka}$ for the end of IRD deposition have been recently reported from the SE Norwegian Sea (Fronval and Jansen, 1996). These ages are in good agreement with core PS1243.

There are some obvious differences in sedimentation rates among our cores, e.g., PS 1243 records an average sedimentation rate of $\sim 4 \mathrm{~cm} / \mathrm{kyr}$ ( $\mathrm{sam}$ ple resolution $\sim 460 \mathrm{yr}$ ) since the Vedde Ash datum whereas PS1246 records only $\sim 1.8 \mathrm{~cm} / \mathrm{kyr}$ (sample resolution $\sim 1000 \mathrm{yr}$ ). In most cores the relation between faunal data on one hand and $\delta^{18} \mathrm{O}$ decrease during Termination I on the other appears to be similar at the end of IRD deposition, implying that oceanographic changes in the Nordic seas since the final stage of the last deglaciation occurred rapidly and without major time lag.

In PS1243 there is a significant increase in polar abundances between 8-7 ka. This cooling event can also be observed in other cores (M17732, M23063)

Fig. 4. Faunal records (\%) of the subpolar species T. quinqueloba (filled circle) and the polar species N. pachyderma sin. (stippled line) since the LGM (MIS 2) in comparison with planktic $\delta^{18} \mathrm{O}$ analyzed on $N$. pachyderma sin. (open circle). The shaded interval represents the marine interglacial optimum $(M I O)$ as interpreted from the faunal evidence. The hatched bar marks the glacial-interglacial transition (Termination I) and the upper limit of this bar the observed last occurrence of deglacial IRD. Grey dots in the graphs of cores M17732, M23352, and PS1243 relate to the $U_{37}^{K^{\prime}}$ temperature estimates (data from Table 2). Note the different scales for the $\delta^{18} \mathrm{O}$ records; $V A=$ Vedde Ash. 
- $\mathrm{T}^{\circ} \mathrm{C}\left(u K^{37}\right)$

$\begin{array}{lllll}8 & 10 & 12 & 14 & 16\end{array}$

Faunal Abundance (\%)
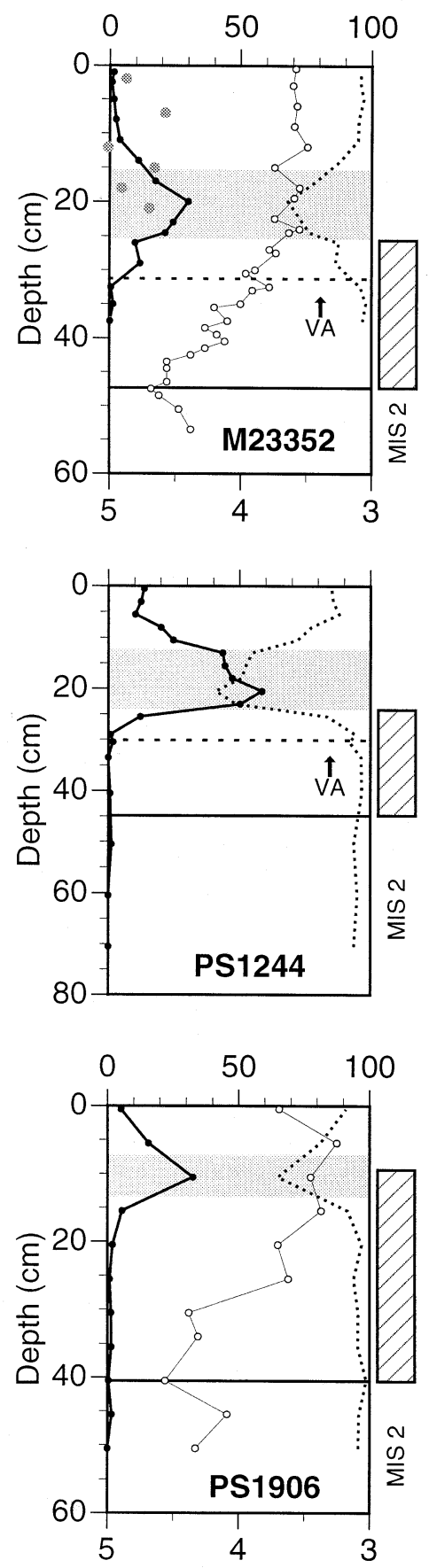

$\delta^{18} \mathrm{O}(\%)$ vs. PDB
- $\mathrm{T}^{\circ} \mathrm{C}\left(u K^{37}\right)$

$\begin{array}{lllll}8 & 10 & 12 & 14 & 16\end{array}$

Faunal Abundance (\%)
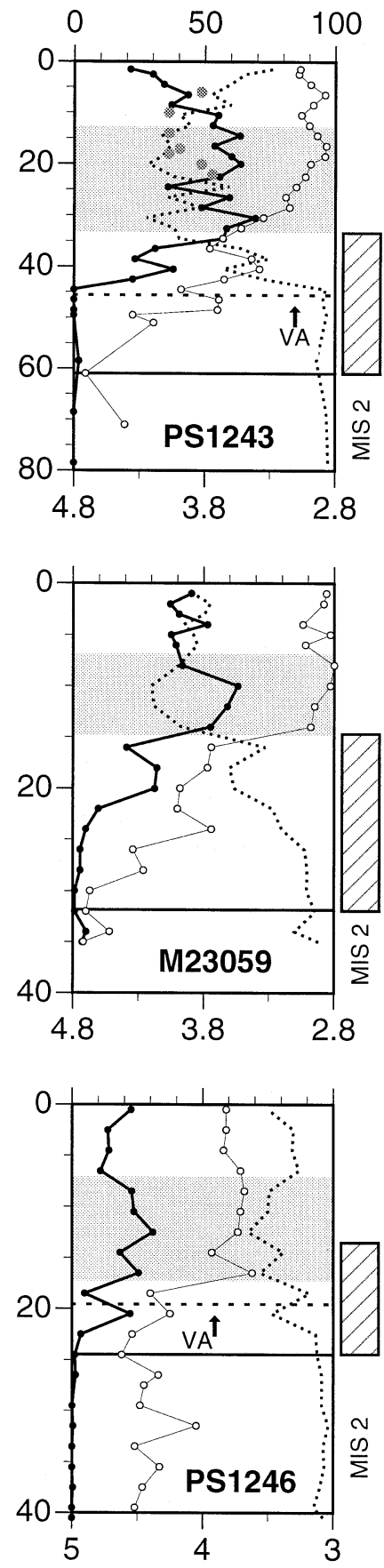

$\delta^{18} \mathrm{O}(\%)$ vs. PDB

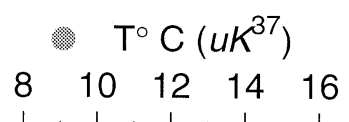

Faunal Abundance (\%)
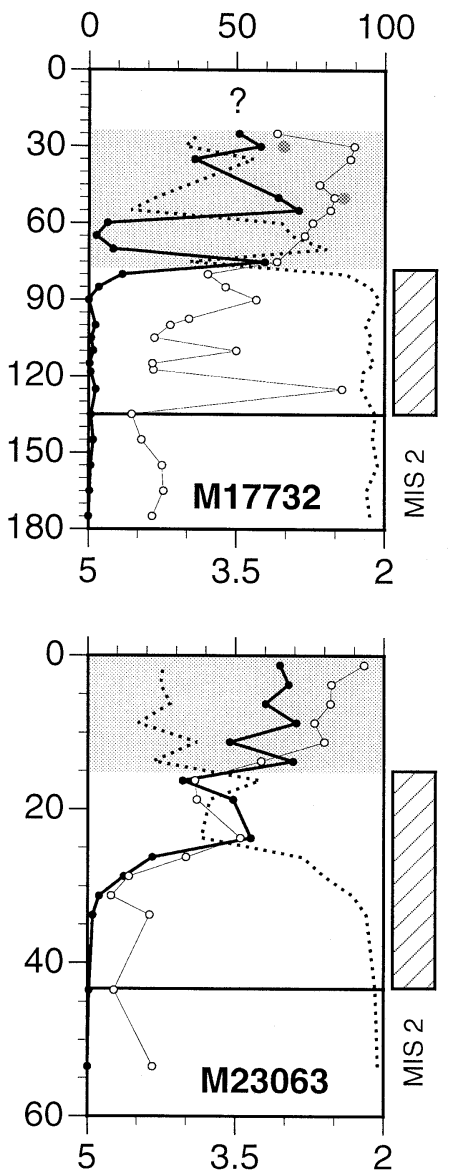

$\delta^{18} \mathrm{O}(\%)$ vs. PDB 


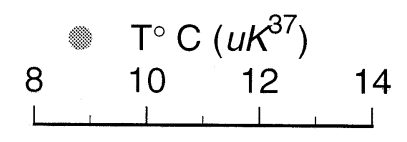

Faunal Abundance (\%)
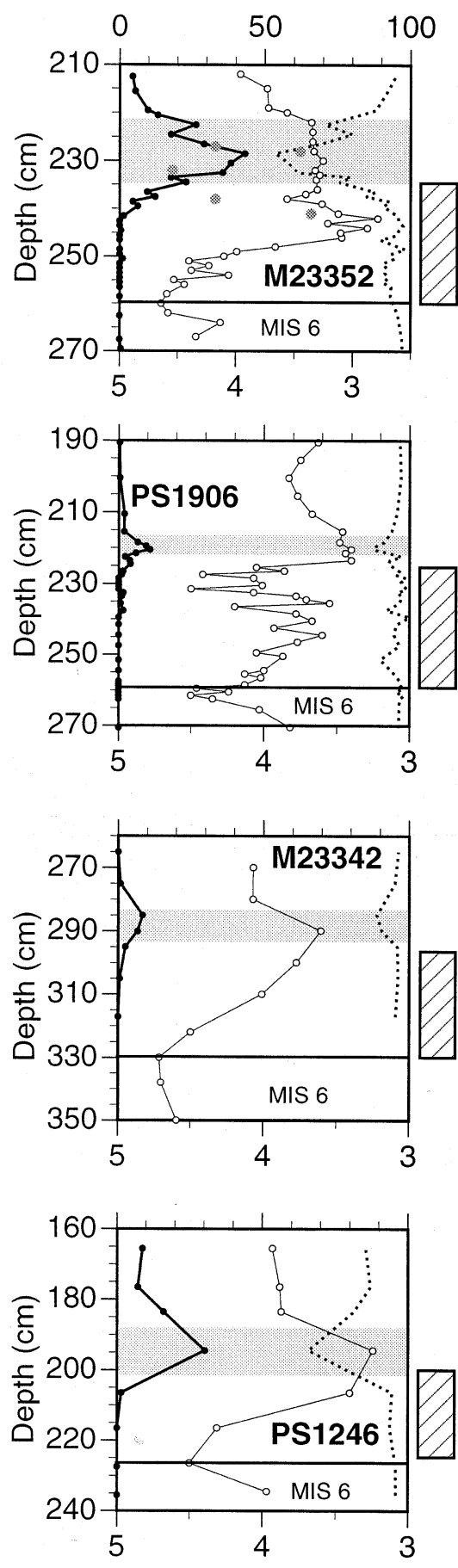

$\delta^{18} \mathrm{O}(\%)$ vs. PDB

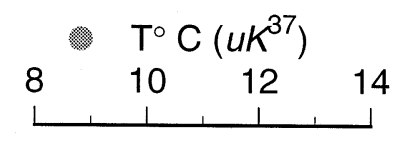

Faunal Abundance (\%)
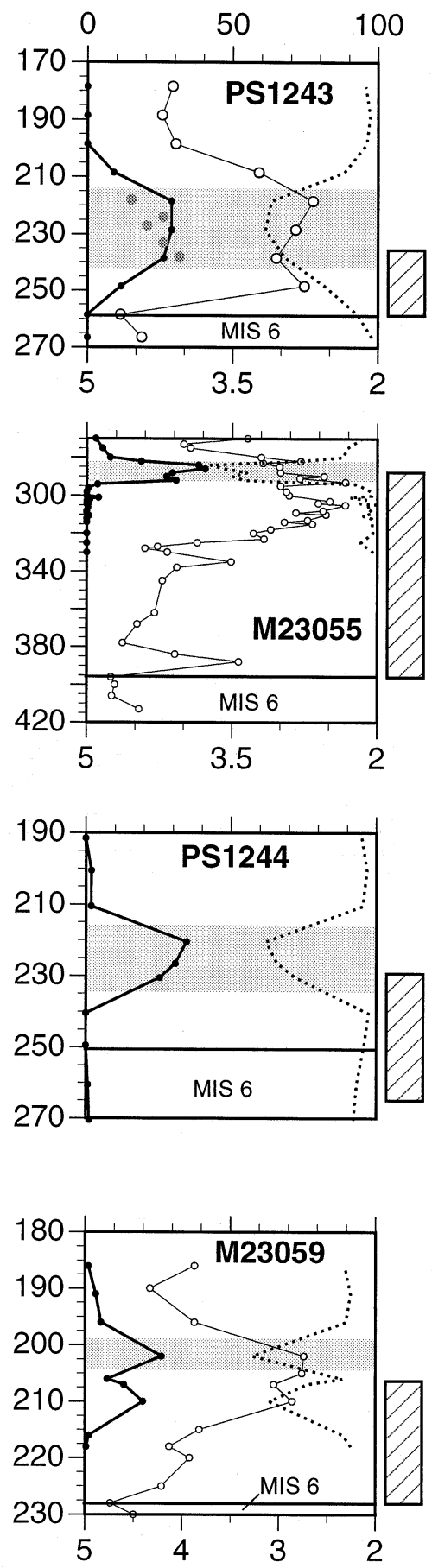

$\delta^{18} \mathrm{O}(\% \circ)$ vs. PDB

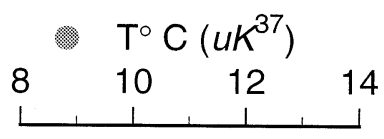

Faunal Abundance (\%)
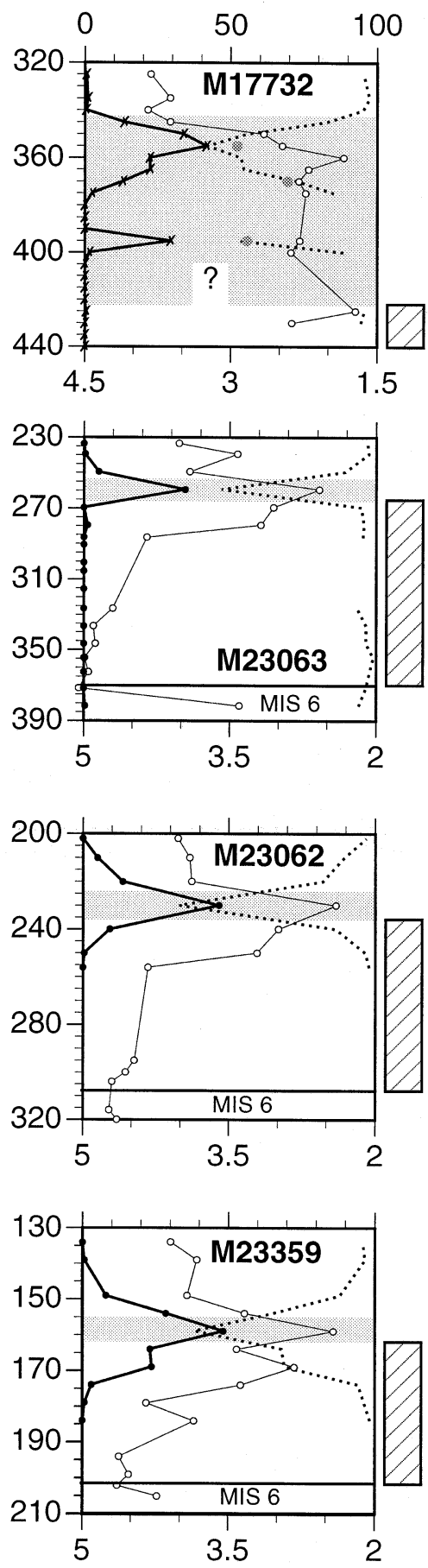

$\delta^{18} \mathrm{O}(\% \circ)$ vs. PDB 
but appears to be restricted to the Norwegian Sea (Bauch and Weinelt, 1997). In general, the faunal records of al cores during the Holocene optimum reflect the present day situation: subpolar abundances are highest along the Arctic Front and within the Atlantic Domain whereas the western part reveals a dominance of the polar species. Another interesting feature is the continuous abundance decrease in subpolar species in the Arctic Domain after 5 ka. Similar changes are also recognized in diatom records from the Iceland Sea (Koç et al., 1993) and in shelf sediments from SE Greenland (Williams et al., 1995). Altogether, these records indicate that the relative temperature gradient in the surface water between the western and the eastern Nordic seas has steepened since the end of the Holocene climatic optimum.

\subsection{Eemian record}

The variations in relative abundances of $T$. quinqueloba and $N$. pachyderma sin. in comparison to the isotope record for the time period of the last interglacial are given in Fig. 5. The highest values of T. quinqueloba correlate well with the upper part of MIS 5e, i.e., the IRD-free section. Like in the Holocene, the increase of this species starts towards the end of the deglacial interval. Within the deglacial core sections $\delta^{18} \mathrm{O}$ records reveal characteristic low values in most cores. These anomalies are recognized in cores from either side of the southern Nordic seas (see cores M23055, M17732, and M23352 in Fig. 5) and it is believed that they reflect meltwater discharge from thawing icebergs paired with increased surface warming due to the rise in solar irradiance during Termination II (Crowley and Kim, 1994; Bauch et al., 1996). In all cores IRD was noted again above the maximum of T. quinqueloba. Together with a simultaneous increase in $\delta^{18} \mathrm{O}$ values (see Figs. 2 and 3) this reappearance of IRD implies enhanced iceberg calving around the Nordic seas and a change in global ice volume towards the end of MIS 5e (Bauch et al., 1996).

\section{Eemian vs. Holocene: palaeoceanographic and climatic implication}

\subsection{Estimates of surface water temperature gradients}

As the data above have shown, among the planktic foraminiferal assemblage Turborotalita quinqueloba has proven to be the best interglacial indicator species in the Nordic seas due to its widespread occurrence only in warm and iceberg-free intervals and, thus, its obvious relation to times of thermohaline water mass circulation. In the ice-free Iceland Sea plankton tow studies have revealed that this symbiont-bearing species predominantly occurs in the upper $50 \mathrm{~m}$ of the water column and within normal marine salinities (Carstens, 1991). This habitat is well above the main calcification depth commonly attributed to $N$. pachyderma sin., which lies deeper, between 100-200 m (Hemleben et al., 1989). In the western areas of the Iceland Sea and the Fram Strait, which are covered by sea-ice and a halocline during summer, T. quinqueloba lives between $\sim 50-100 \mathrm{~m}$ water depth and distinctly within the higher salinity waters (Carstens, 1991; Carstens et al., 1997). This indicates that $T$. quinqueloba usually despises brackish waters, an assumptions which seems consistent with our observation of highest abundance of this species only during IRD-free core intervals. It can thus be concluded that the maxima in abundance of T. quinqueloba noted for the Holocene and the Eemian reflect times of full-marine conditions during these two interglaciations, at least with regard to sea surface salinities which in this area are inherently linked to the advection of relatively high-salinity $\mathrm{N}$. Atlantic surface water.

In terms of 'absolute' SST difference between the

Fig. 5. Eemian faunal records (\%) of the subpolar species T. quinqueloba (filled circle) and the polar species $N$. pachyderma sin. (stippled line) in comparison with planktic $\delta^{18} \mathrm{O}$ analyzed on $N$. pachyderma sin. (open circle). The shaded interval represents the marine interglacial optimum (MIO) as interpreted from the faunal evidence. The hatched bar marks the glacial-interglacial transition after MIS 6 (Termination II) and the upper limit of this bar the observed last occurrence of deglacial IRD. Grey dots in the graphs of cores M17732, M23352, and PS1243 relate to the $U_{37}^{K^{\prime}}$ temperature estimates (data from Table 2). Note the different scales for the $\delta^{18} \mathrm{O}$ records. 


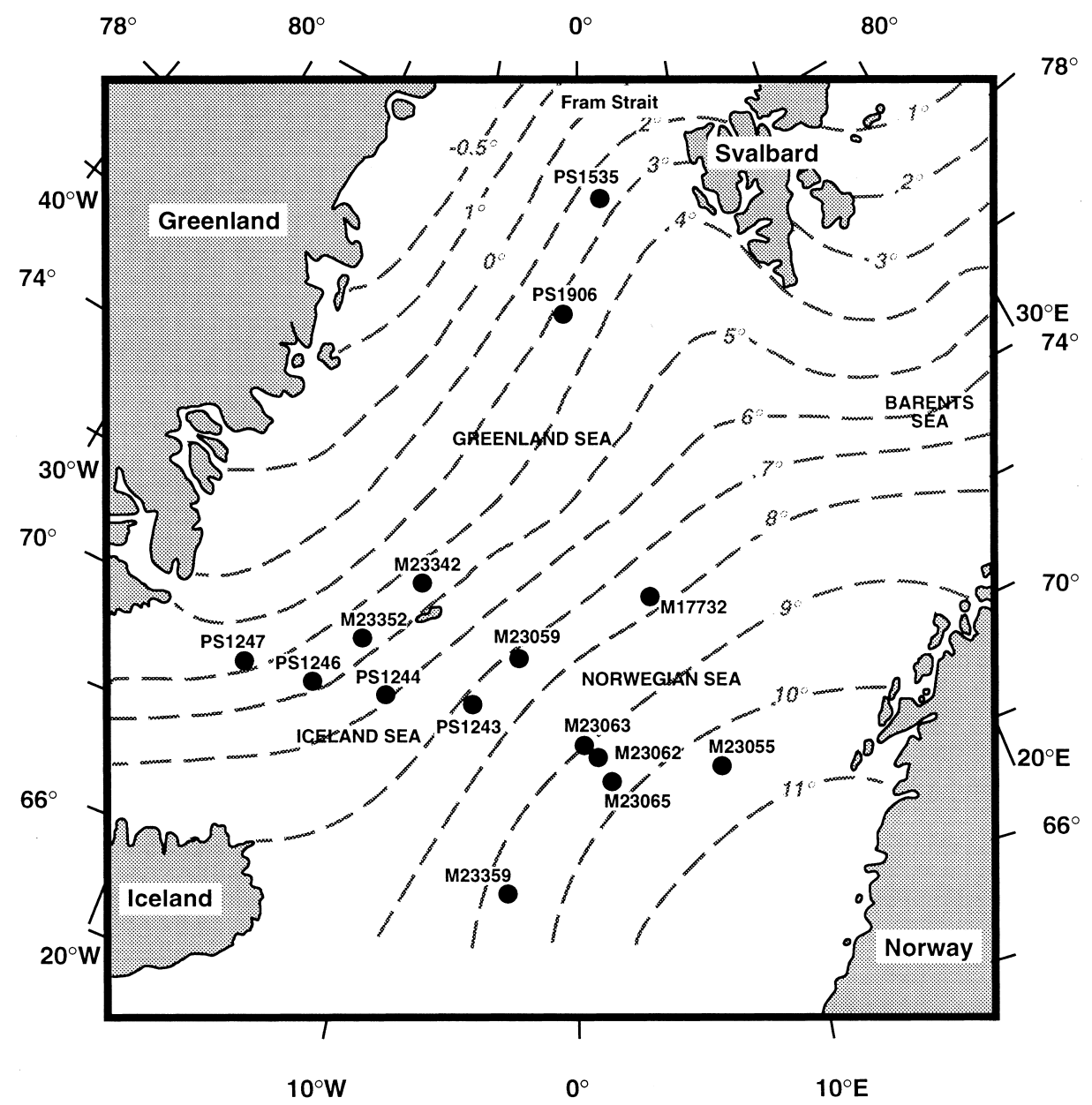

Fig. 6. Modern mean SSTs in the Nordic seas for the summer months of the period 1950-1990 (Environmental Working Group, 1998). Both, $U_{37}^{K^{\prime}}$-derived SSTs and the faunal records from the Holocene reveal geographical gradients, which are similar to this modern SST distribution (compare with Figs. 4 and 5).

two interglaciations, the results of the alkenone analyses are given in Table 2 for cores M23352, PS1243, and M17732 (along an E-W transect at about $70^{\circ} \mathrm{N}$ ). We also have analysed core PS1906 from the Boreas Basin but failed to find any alkenone signal in the Eemian core section and only traces were detected in Holocene samples. Compared with the modern SSTs the $U_{37}^{K^{\prime}}$-derived average SSTs for the Holocene fit modern temperature distribution in general pattern but not in absolute value (Table 2; Figs. 4-6). This deviation from the modern distribution may be due either because we mainly analysed the climatic optimum or the common $U_{37}^{K^{\prime}}$-temperature calibrations are not perfectly adjusted to estimate the relatively cold SSTs in a polar-subpolar region. We do not regard the short evolutionary changes in coccolithophorid species composition as a problem, because Emiliani huxleyi and species of the genus Gephyrocapsa are also present in Eemian sediments from the Nordic seas (Bleil and Gard, 1989; Baumann, 1990). Moreover, recent downcore studies indicate that both of these groups produce comparable $\mathrm{C}_{37}: \mathrm{C}_{38}$ alkenone ratios (Müller et al., 1997). Regardless of these various problems, the average $U_{37}^{K^{\prime}}$-temperatures calculated for the Holocene and Eemian at the three investigated sites clearly corroborate the trends inferred from the relative proportions of subpolar and polar foraminifera: Site M23352 

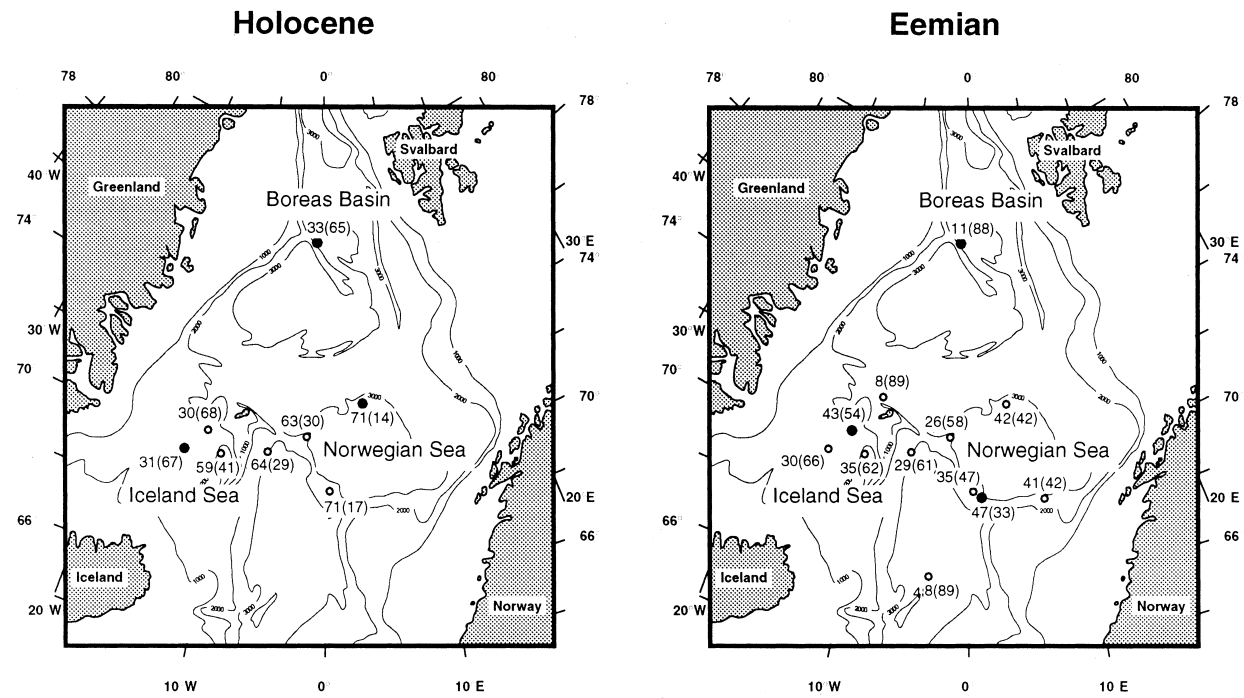

Fig. 7. Geographical distribution of faunal data (\%) from Figs. 4 and 5 for the Holocene and Eemian MIOs, respectively. Numbers in parentheses refer to $N$. pachyderma sin. and the other numbers to T. quinqueloba. Due to different sampling intervals applied on the interglacial core sections, the shown numbers of T. quinqueloba are the highest observed in a specific region - for $N$. pachyderma sin. the lowest — and are, therefore, equal or smaller than the actual peak abundance of the MIO. Despite some differences in sample density applied to Holocene and Eemian core intervals, our values of $N$. pachyderma sin. (\%) agree with other data from this area (Fronval and Jansen, 1997).

shows a warmer Eemian than Holocene whereas in cores PS1243 and M17732 SSTs appear cooler in the Eemian than in the Holocene.

By using the maximum values of the faunal data given in Figs. 4 and 5 it is possible to deduce a basic palaeoceanographic scenario for the Holocene and Eemian MIOs. From this it follows that both of these intervals show a general south to north decrease in subpolar abundance (Fig. 7). However, there are marked regional differences, that is, in the gradients between the Norwegian Sea in the east, the Iceland Sea in the west, and the Boreas Basin in the north. During the Holocene by far the highest subpolar abundances occur at the eastern sites directly underlying today's flowpath of Atlantic surface water. These Holocene subpolar values decrease towards the north and the west, i.e., towards those regions with increasingly cooler modern surface water conditions (Fig. 6). In contrast, the Eemian faunal values display relatively similar conditions between the Norwegian and the western Iceland Sea but a sharp decrease towards the Greenland Sea and the Boreas Basin. Although Eemian conditions were equally favourable for $T$. quinqueloba approximately south of $70^{\circ} \mathrm{N}$, they were comparatively better in the western Iceland Sea in the Eemian than in the Holocene.

It has been interpreted from surface sediment analyses that $T$. quinqueloba may be tied to watermass frontal zones, in particular to the Arctic Front (Johannessen et al., 1994). Indeed, we also note relatively high abundances in Holocene sections at sites close to this frontal zone (cores PS1243, M23059). From this one could draw the conclusion that during the Eemian the Atlantic Domain (i.e. the Arctic Front) had shifted westwards at the expense of the Arctic Domain. But besides that we observe the highest abundances of T. quinqueloba at these sites during the Holocene climatic optimum (and also further east of the Arctic Front), a possible westward shift in Eemian times is not confirmed by other data. In core PS1244, Eemian test concentrations of $G$. bulloides, a typical indicator for Atlantic waters in the Nordic seas, remain as low as in the Holocene. Farther west and north this species is not present in either interglaciation (Bauch, 1997). Nevertheless, it seems that the SE Norwegian Sea was still relatively warm during the Eemian. This may be assumed from 

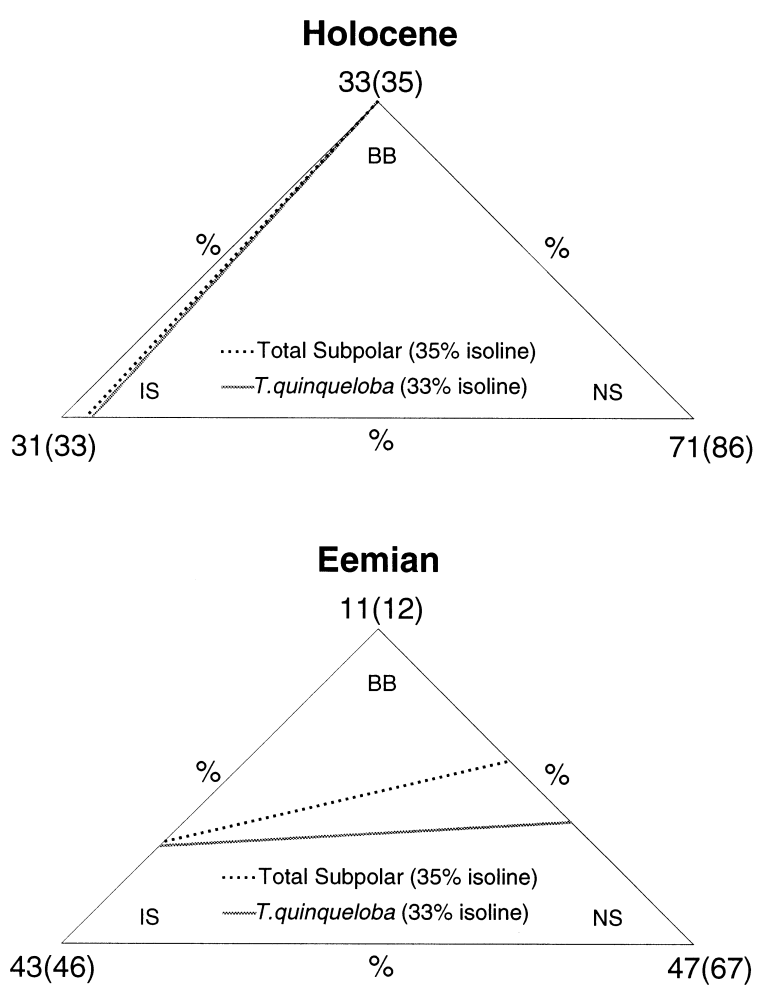

Fig. 8. Schematic palaeoceanographic models of the inferred regional differences in surface water properties of the Nordic seas for the Holocene and Eemian MIOs based on the relative abundance of (1) T. quinqueloba and (2) total subpolar species (in parentheses) - the latter are inversely related to $N$. pachyderma sin. The numbers at the tips of the two triangles represent the maximum faunal values taken from those sites in Fig. 7, which are indicated by a filled circles (note the different scales for each side and each group). The two isolines can be interpreted as the main oceanographic fronts of the two interglaciations. $B B=$ Boreas Basin; $I S=$ Iceland Sea; $N S=$ Norwegian Sea.

the relatively higher proportions of subpolar species other than T. quinqueloba out of the total subpolar fauna (Fig. 8) observed at the Vøring Plateau (82\% in the Holocene but just $70 \%$ in the Eemian) which may became advected to this area from a relatively warm southern source.

Based on the simple oceanographic models in Fig. 8, it is suggested that the major oceanographic front in the Eemian - we infer that SST isolines would have run roughly parallel to this front - was aligned in a zonal E-W pattern whereas Holocene SST isolines run in a meridional pattern similar to the present day situation (Fig. 1).

\section{2. $\mathrm{CaCO}_{3}$ and $\delta^{18} \mathrm{O}$ as water mass proxy}

Previous studies of calcium carbonate analyses (bulk weight \%) support our faunal results which in the western Iceland Sea show higher carbonate contents during the Eemian than during the Holocene (Baumann et al., 1993). Today benthic and planktic foraminiferal tests are well preserved in most parts of the Nordic seas. Only in the Polar Domain along the East Greenland continental margin, where the EGC flows from the Arctic Ocean southward, we observe very severe fragmentation of foraminiferal tests (R.F. Spielhagen unpubl. data). In the western Iceland Sea, the topographic high of the Kolbeinsey Ridge (Fig. 1) rises on average above $900 \mathrm{~m}$ water depth. This ridge seems to act as a kind of 'carbonate dissolution barrier', thereby preventing the intrusion of corrosive, presumably deeper, waters from the East Greenland continental margin onto the Iceland Plateau. This is concluded because Holocene carbonate values range between $16-40 \%$ on the eastern side of the ridge, but are far below $10 \%$ just west of the Kolbeinsey Ridge (Lackschewitz, 1991; Baumann et al., 1993). In core PS1247 from close to the continental slope of Greenland (Fig. 9) the carbonate content is $<1 \%$ during the Holocene, but rises to $\sim 15 \%$ during the Eemian. A visual check of the sand-size fraction revealed T. quinqueloba in the Eemian interval and obviously less corrosion of foraminiferal tests. Almost no specimens of T. quinqueloba were to be found throughout the Holocene section where all foraminiferal tests appear extremely fragmented. In core PS1247 it is not feasible to use an abundance record of T. quinqueloba as proxy because the dissolution effects may have caused a major alteration of the original species composition. Nevertheless, the general difference in test corrosion between the two interglaciations of this core give further evidence that water mass properties were obviously not of the same kind for both intervals.

During warm interglacial periods coccoliths in the Nordic seas comprise a substantial part of the fine carbonate in the sediments whereas the coarse carbonate mainly consists of foraminifera. In the Eemian section of M23352 (Fig. 10), the coarse carbonate clearly exceeds Holocene values whereas fine carbonate remains low. Results from the Nordic seas based on the Holocene coccolithophorid assem- 


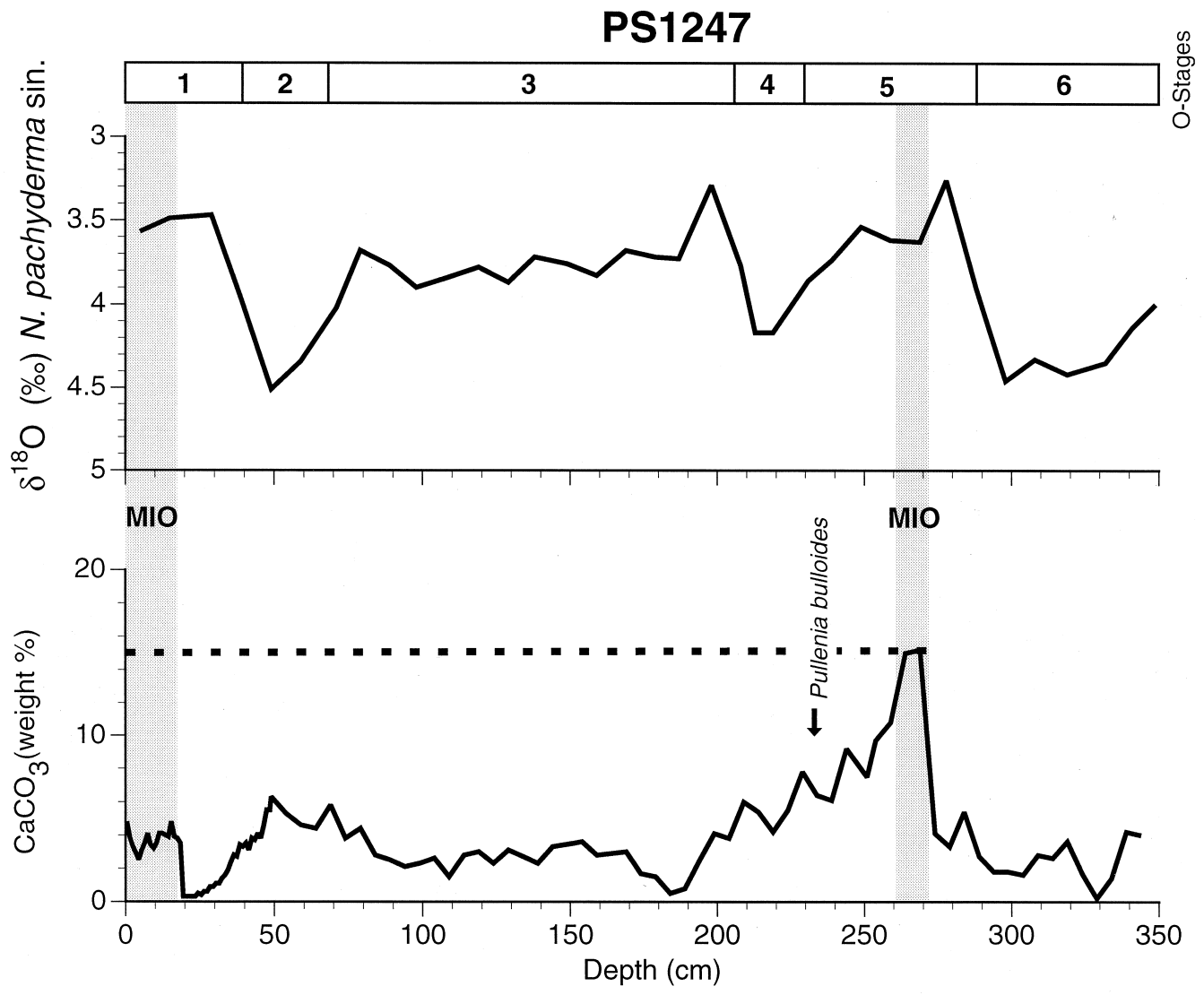

Fig. 9. Records of $\mathrm{CaCO}_{3}$ and $\delta^{18} \mathrm{O}$ of core PS1247 from the Greenland continental margin and below the modern track of the cold East Greenland Current (note the much larger sample intervals applied to the $\delta^{18} \mathrm{O}$ record). Shaded bar marks the interval which is interpreted as the correlative of the Eemian and Holocene MIO, respectively. The stratigraphic position of the Eemian MIO is confirmed by a high peak in $\mathrm{CaCO}_{3}(260-270 \mathrm{~cm})$ which coincides with highest and lowest proportions of foraminifera and IRD respectively, as well as by the identification of the Pullenia bulloides horizon $(\sim 230 \mathrm{~cm})$ as stratigraphic marker for MIS 5a in this core (Birgisdottir, 1990). Foraminiferal tests in the Holocene section are less fragmented than in the Eemian interval, implying less $\mathrm{CaCO}_{3} \mathrm{Corrosion} \mathrm{CaCO}_{3}$ data are from Birgisdottir (1990) and the $\delta^{18} \mathrm{O}$ record is from Köhler (1992).

blage (mainly 3 species) show a dominance of the 'cold' species C. pelagicus (Samtleben et al., 1995), which in core M23352 makes up between $80-90 \%$ of the total assemblage. This species is absent in the Eemian section of this core $(\mathrm{H}$. Andruleit unpubl. data).

Can the spatial and temporal trends in T. quinqueloba abundance and carbonate patterns also be recognized in stable isotope data? As already noted in core M23065 (Fig. 2), the level of oxygen isotope values of Holocene and Eemian times do not differ much at the Vøring Plateau, where the main mass of warm Atlantic surface water enters the Nordic seas. Therefore significant interglacial climate changes are probably difficult to identify here. They should be more pronounced where temperature gradients are steeper, i.e., closer to Greenland. The detailed planktic $\delta^{18} \mathrm{O}$ record of core M23352 from the NW Iceland Plateau (Fig. 10) corroborates our findings based on T. quinqueloba and $\mathrm{CaCO}_{3}$ : the Eemian interval differs significantly from the Holocene. The constantly lower Eemian $\delta^{18} \mathrm{O}$ values of $\sim 0.25 \%$ o during the IRD-free intervals would indicate a temperature difference of about $1^{\circ} \mathrm{C}$ (Epstein et al., 1953) at the main calcification depth of $N$. pachyderma sin., which appears to lie between 100-200 m water depth even in ice-covered regions (Carstens and Wefer, 1992; Bauch et al., 1997). Therefore, an effect 


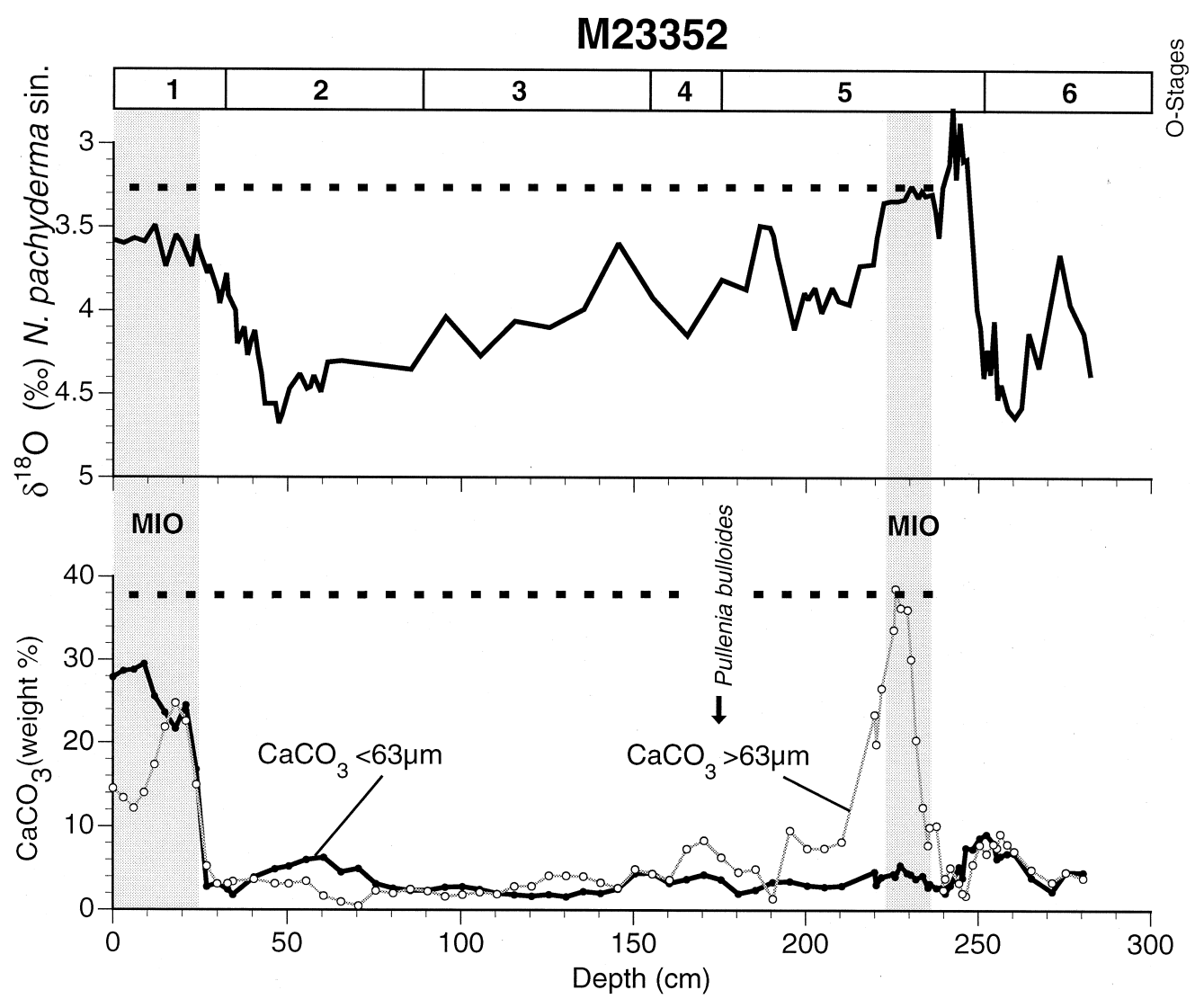

Fig. 10. Planktic $\delta^{18} \mathrm{O}$ and $\mathrm{CaCO}_{3}$ content from the NW Iceland Plateau. Note the significant Holocene/Eemian discrepancy in $\delta^{18} \mathrm{O}$ values and the differences between fine and coarse $\mathrm{CaCO}_{3}$ content. Shaded bars mark IRD-free core sections (MIO). The prominent spike in the $\delta^{18} \mathrm{O}$ record prior to the Eemian MIO seems to correlate with a spike recorded in core PS1247 at a similar stratigraphic level (Fig. 9).

of other freshwater sources, e.g. from sea-ice melting, river run-off, or precipitation that might have led to a lowering of these Eemian $\delta^{18} \mathrm{O}$ values can also be ruled out, because these would occur at the very surface. Moreover, the inference that relatively normal marine salinities existed in the upper surface water during this time is further corroborated by the presumed ecological preference of $T$. quinqueloba to live within a certain range of full-marine salinities (Carstens et al., 1997).

From carbonate content, T. quinqueloba abundance as well as from the planktic $\delta^{18} \mathrm{O}$ and $U_{37}^{K^{\prime}}$ records we may conclude that during the Eemian MIO the influence of the cold Polar Domain on the surface water temperature of the western Iceland Sea was weaker than in the Holocene MIO.
A strong Eemian decrease of $T$. quinqueloba abundances towards the north is well documented in our cores, even though this is not really seen in the $\delta^{18} \mathrm{O}$ values (Figs. 4 and 5). But closer to the Fram Strait, there is further evidence that the Eemian was indeed less 'warm' as an interglacial than the Holocene (Fig. 11). Here, the $\delta^{18} \mathrm{O}$ curve shows a shift of more than $1.4 \%$ o since the LGM. This is in contrast to the transition from MIS 6 to MIS 5e, which only varies between 0.7 to $1.0 \%$. As documented in many benthic $\delta^{18} \mathrm{O}$ records from outside the Nordic seas, there is no reason to believe that the global ice volume was significantly smaller in MIS 6 than in MIS 2 (e.g., Shackleton, 1987; see also Fig. 2). Assuming that about $1 \%$ of the total $\delta^{18} \mathrm{O}$ change since the LGM can be attributed to the global 


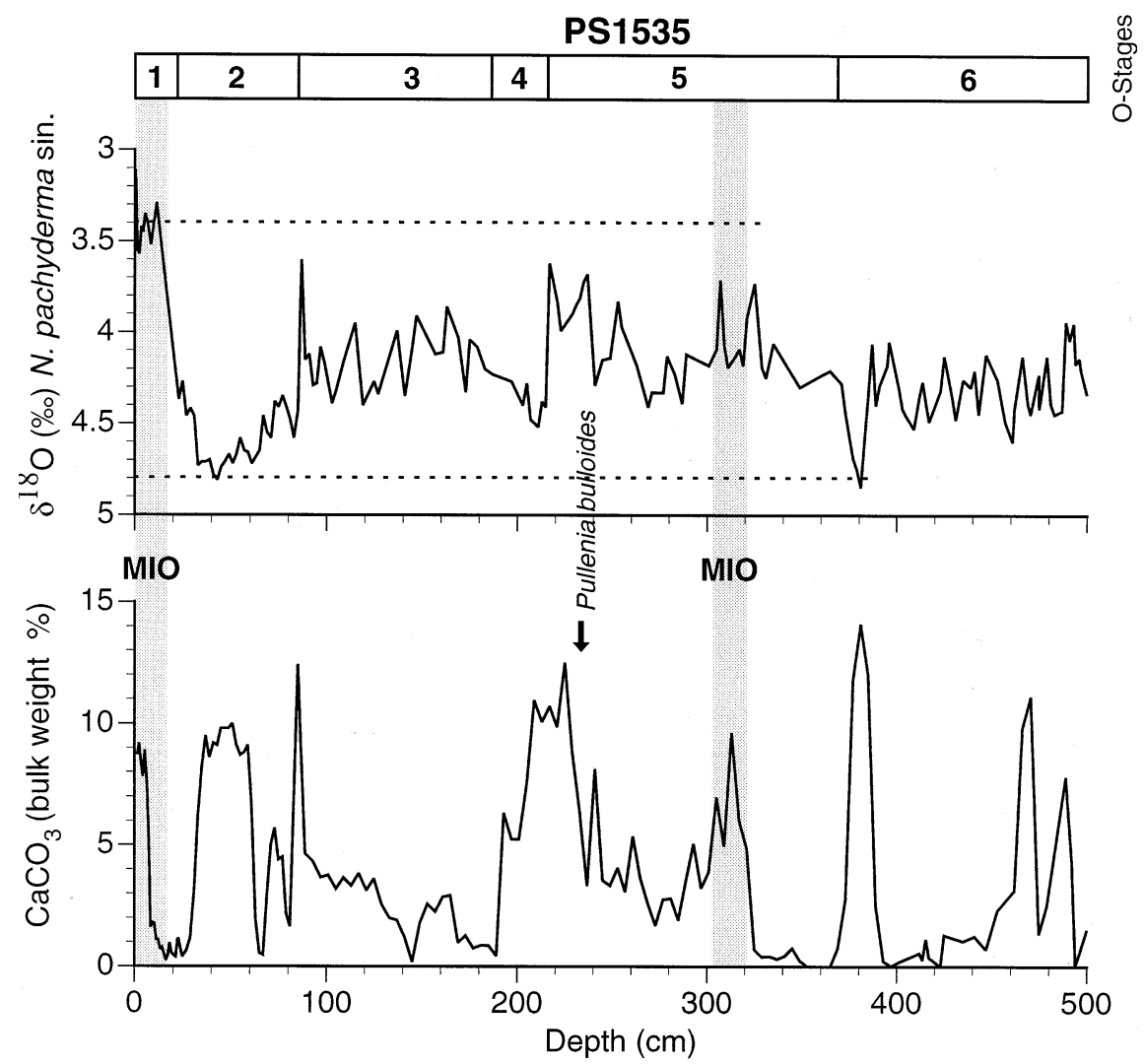

Fig. 11. Planktic $\delta^{18} \mathrm{O}$ and $\mathrm{CaCO}_{3}$ records from the Fram Strait area. Note the relative difference in the $\delta^{18} \mathrm{O}$ values between the two MIOs. In contrast, similar $\delta^{18} \mathrm{O}$ values are recorded for the glacial maxima of late MIS 6 and 2 (compare with, e.g., Fig. 10).

ice volume effect (Schrag et al., 1996), the remaining $0.4 \%$ observed in core PS1535 are either due to enhanced freshwater input or a temperature increase. In all our studied cores planktic $\delta^{18} \mathrm{O}$ records from the Nordic seas based on $N$. pachyderma sin. show $\delta^{18} \mathrm{O}$ values of about $4.5-4.8 \%$ or for the glacial maxima of MIS 2 and 6, indicating similar SSTs and surface salinities for these two periods. Such values are also recorded for core PS1535, implying that the relatively small change of about $0.7-1 \%$ o during Termination II is either due to relatively cold surface water or caused by a smaller input of freshwater from melted ice. A freshening of the surface water in this region would be obviously also directly linked to a temperature increase.

In Core PS1535 it is not a supposedly warm Eemian section that reveals the lowest oxygen values during MIS 5, but the later event MIS 5a (Köhler and Spielhagen, 1990). The stratigraphic position of
MIS 5a in this core is clearly recognized by the occurrence of the benthic foraminifera Pullenia bulloides, which can be used as stratigraphic indicator for MIS 5a (Haake et al., 1992), whereas MIS 5e is also confirmed through nannoplankton studies (Baumann, 1990). A relatively cold Eemian in the Fram Strait region has been also interpreted by others investigating coccolith abundances, various marine sedimentological proxies as well as bivalves around Svalbard (Gard and Backman, 1990; Hebbeln and Wefer, 1997; Mangerud et al., 1998). Although the last glacial to Holocene climate change is also well documented in planktic $\delta^{18} \mathrm{O}$ records from the Arctic Ocean proper (Stein et al., 1994; Nørgaard-Pedersen et al., 1998), a similar $\delta^{18} \mathrm{O}$ signal for the Eemian period is not recognizable (Nørgaard-Pedersen, 1997; Spielhagen et al., 1997), implying a different type of ocean circulation in the sub-arctic region during the latter period. 


\section{Palaeoceanographic implication of Eemian temperature gradients}

The modern surface water circulation pattern of the northern Nordic seas reveals that still relatively warm Atlantic surface water of about $2^{\circ} \mathrm{C}$ intrudes the eastern Arctic Ocean via Fram Strait by subduction below the cold halocline and across the Barents Sea (Rudels, 1995; Environmental Working Group, 1998). To maintain a mass-balanced water budget in the Arctic Ocean, only as much water can leave the Arctic Ocean as is replaced by Atlantic water $(\sim 5-6$ Sv; Hanzlick, 1983) of which most flows through Fram Strait, as well as by water from the Pacific Ocean ( $0.8 \mathrm{~Sv}$; Coachman and Aagaard, 1988) and Arctic rivers $(\sim 0.1 \mathrm{~Sv}$; Aagaard and Carmack, 1989).

Based on the conclusions reached before, the EGC, which is the main source of cold upper water in the Polar Domain of the Nordic seas today, did probably not protrude as far south during the Eemian as during the Holocene. This Eemian situation can be explained by a pattern of ocean circulation in which the Fram Strait area (and eastern Arctic Ocean) was somehow shut off from a modern-type water mass exchange, and only little Atlantic water reached this Arctic region. A reduced advection of Atlantic water masses would not only have led to a decrease in the northwardly directed ocean heat flux, but would have also resulted in a much weaker outflow of cold polar water from the Arctic Ocean itself (Fig. 12). Today, cold polar surface waters flow along the East Greenland continental margin southward and across the Greenland and Iceland seas and accounts for much of the observed cold SSTs in these areas. A similarly cold western Iceland Sea cannot be inferred from any of the shown data for the Eemian. Instead, the main mass of inflowing warm Atlantic water remained in the southern part of the Nordic seas.

So, why did the Atlantic surface water during the Eemian not influence also the northern Nordic seas the way it happens today and during most of the Holocene? The answer to this important question is somewhat speculative because the history of Saalian (MIS 6) ice sheet decay in Fenoscandia as well as the impact of the meltwater from these ice sheets on the surface water circulation in the Nordic seas is rather uncertain. For the deglacial and postglacial time after MIS 6 this impact must be assumed to have been at least as strong as during Termination I (Sarnthein et al., 1995) and the early Holocene (Bauch and Weinelt, 1997). As can be inferred from our own data (see Figs. 2 and 3) and data of other sediment cores from the eastern Norwegian Sea (e.g., Fronval and Jansen, 1997), Termination II penetrated far into MIS 5e, making a substantial part of the MIS 5e interval to have been influenced by meltwater. Freshening the surface water in the Norwegian Sea during this time would have caused salinities less suitable for most planktic foraminifera and may have promoted sea-ice formation during winter season. It further would have stratified the upper water column, conditions which are thought to have an enormous effect on surface water circulation (Dickson et al., 1988; Broecker and Denton, 1989; Rahmstorf, 1995). The fact that in the northern Norwegian Sea the part of MIS 5e with highest test concentrations of subpolar species is still associated with some IRD may indicate lowered salinities even within the MIO (Fig. 3). If the northern Norwegian Sea surface water was indeed marked by relatively low salinities in the Eemian MIO compared to the Holocene, these fresher waters in the northern Norwegian could have forced most of the more saline Atlantic surface water towards the west rather than allowing it to flow further north (Fig. 12).

A variable watermass exchange between the Arctic Ocean and the Nordic seas may be an important control on the interglacial climate system with consequences for the entire N. Atlantic sector. The proposed Eemian zonal surface circulation would result in a much steeper meridional temperature gradient in the eastern Nordic seas than is indicated for the Holocene. Previous investigations on the last interglaciation have not revealed a major deviation from the Holocene situation (Kellogg, 1980; Sejrup and Larsen, 1991). Our steep Eemian temperature gradient probably occurred along a front that run roughly East-West at about $70^{\circ} \mathrm{N}$ rather than between the Nordic seas and the NE Atlantic as suggested by other investigators who had only very few data from a limited area of the Nordic seas at their hands (Cortijo et al., 1994; Labeyrie et al., 1995).

The paleoclimate and palaeoceanographic consequences of our inferred steep temperature gradient at $70^{\circ} \mathrm{N}$ and a partially warmer southern Nordic seas 


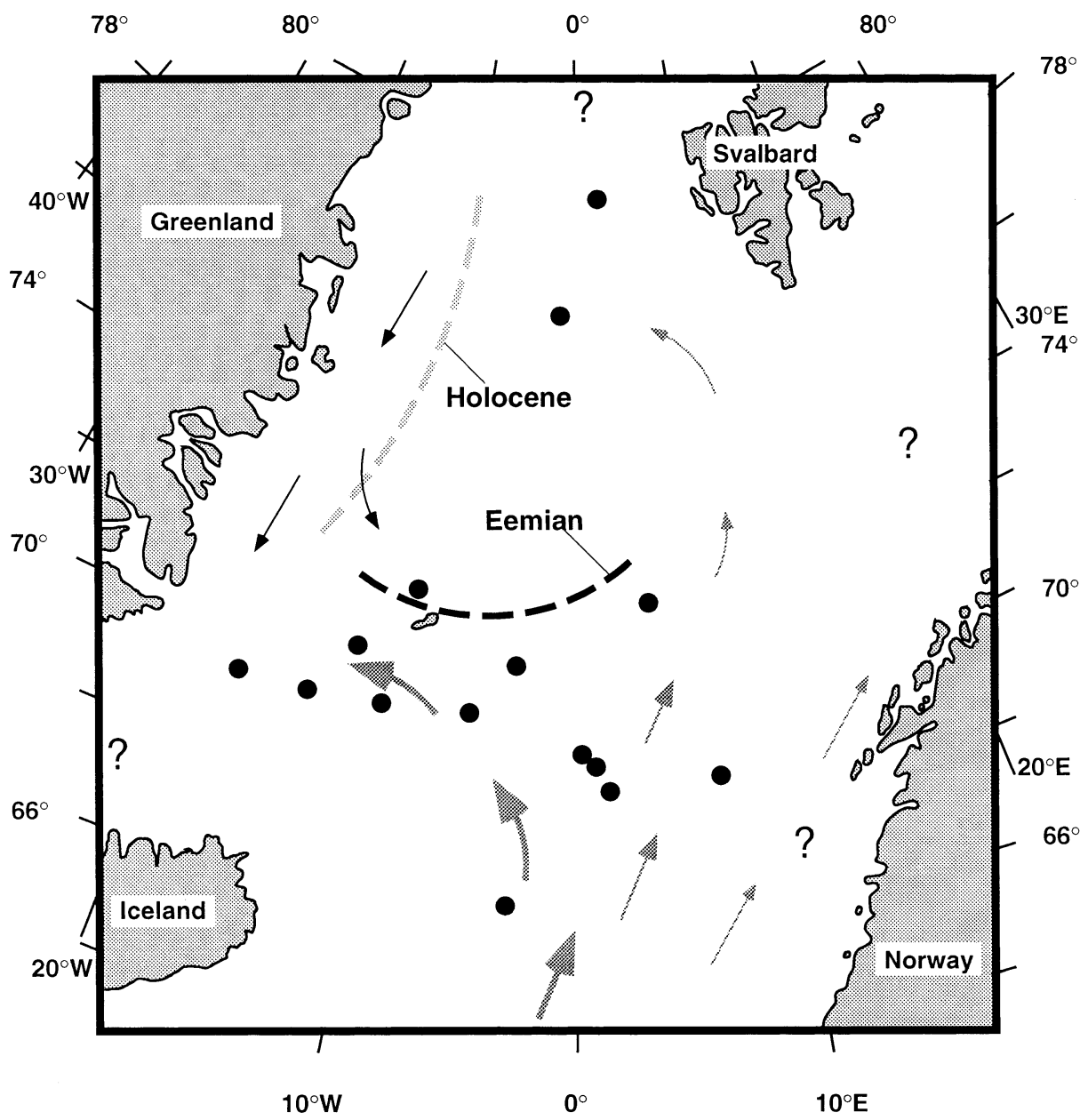

Fig. 12. Proposed surface water circulation for the Eemian marine interglacial optimum (dots indicate studied sites). It shows a reduced advection of warm Atlantic water (grey arrows) towards the north and into the Arctic Ocean, consequently leading to a relatively weak influence of cold polar waters (black arrows) farther south in the western Iceland Sea. Because most of the Atlantic water remained in the southern Nordic seas and flowed close to Greenland, the Eemian main oceanographic front (black dashed line) was aligned east-west rather than south-north like in the Holocene (dashed stippled line). That the little Atlantic water which reached the northern Nordic seas during the Eemian was also flowing northward along the eastern part of the Nordic seas due to coriolis forcing can be inferred from recently published data from the central Greenland Sea, which show more than $95 \%$ of $N$. pachyderma sin. throughout the Eemian interval (Fronval and Jansen, 1997). The data base used for our study does not allow to speculate about the consequences of this Eemian circulation pattern on the rates of deep water formation in the Iceland and Greenland seas.

for the Eemian than for the Holocene may have also led to a relatively reduced SST difference between the southern Nordic seas and the NE Atlantic during the Eemian. Previous interpretations of terrestrial data from the Eemian have indicated $1-3^{\circ} \mathrm{C}$ higher temperatures than in the Holocene for the western European mid-latitudes south of $60^{\circ} \mathrm{N}$ (Velichko et al., 1984; Guiot et al., 1993). Furthermore, recent es- timates of SSTs from the NE Atlantic (between 40$50^{\circ} \mathrm{N}$ ) based on alkenones also record higher values for the Eemian than for the Holocene (Villanueva et al., 1998 in press). These higher SSTs for the Eemian in this area also agree with a ca. $2^{\circ} \mathrm{C}$ difference deduced from planktic foraminiferal data (Ruddiman et al., 1986). 


\section{Conclusions}

Sediment core sections from the Nordic seas covering the Eemian and Holocene intervals were investigated. A multiproxy approach based mainly on the polar/subpolar proportion in the planktic foraminiferal assemblage, planktic and benthic foraminiferal $\delta^{18} \mathrm{O}$ records, $\mathrm{CaCO}_{3}$ as well as IRD contents supported by $U_{37}^{K^{\prime}}$-SST estimates was used in order to allow for a detailed comparison of the surface water circulation pattern of these two warm periods. Only the proxy data from those parts of the two interglaciation were used for this comparison which are characterized by lowest IRD content and highest proportion of warm surface water indicating subpolar foraminifera. These parts are, thus, interpreted as the time of the marine interglacial optimum.

All the proxy records investigated indicate for the Eemian a comparatively cooler northern Nordic seas (ca. north of $70^{\circ}$ latitude) than for the Holocene due to a reduction in the northwardly flow of Atlantic surface water on one hand and, consequently, less outflow of polar waters from the Arctic Ocean on the other. For the southern part of the Nordic seas slightly higher Eemian sea surface temperature can be deduced from our data for the western Iceland Sea compared to the Norwegian Sea, which is contrary to the Holocene situation. The IRD records in relation to subpolar abundance and $\delta^{18} \mathrm{O}$ clearly indicate that Termination II penetrated far into MIS 5e, possibly due to reduced salinities in the surface water of the northern Norwegian Sea. Such conditions may have affected surface water circulation in the way that despite coriolis forcing most of the Atlantic water was deflected into the Iceland Sea rather than flowing further north towards Fram Strait and into the Arctic Ocean as today. The particular Eemian conditions resulted in a zonal surface water circulation with a steep meridional temperature gradient in SSTs.

If our Eemian scenario of a strong meridional temperature gradient between the Arctic Ocean and southern Nordic seas is correct, then this situation should have left an imprint on the polar regions itself. A relatively cold northern Eurasian margin could have resulted in more glaciated areas with consequences for the atmospheric circulation patterns, sea-ice cover, and albedo at these high northern lati- tudes. Obviously, this hypothesis may be difficult to prove in those areas which after the Eemian were overrun by the Fenoscandian, Barents and Kara ice sheets of Weichselian age. Instead such evidence may be preserved in biotic records from Arctic Siberia, a region which is far beyond Atlantic moisture supply and which, therefore, probably remained rather unaffected by the dynamic behaviour of large ice sheets.

The revealed fundamental differences between the Eemian and Holocene periods indicate that a one to one modern climatic analog may be difficult to find in late Quaternary records. But the data also show that Eemian climate conditions are still in many respect Holocene-like. Therefore, this period remains an object well suited for climate modelling, because it can be studied from its beginning after glacial MIS 6 until it terminated towards MIS 5.4. Moreover, since highest temperatures exceeded those of the Holocene optimum and sea level was higher by several meters, the marine records of the Eemian should provide important information of those changes which may occur in the near future.

\section{Acknowledgements}

We are indebted to the shipboard crews of RV Meteor and RV Polarstern for collecting the sediment cores from the Nordic seas. Thanks are also expressed to the Deutsche Forschungsgemeinschaft for providing most of the financial support to carry out this study through Sonderforschungsbereich 313 at Kiel University (Publication No. 316). We are also grateful to W.W. Hay for comments on the text, to R. Cheddadi and G. Ganssen for their helpful reviewing remarks, and to L. Timokhov for making available new oceanographic data.

\section{References}

Aagaard, K., Carmack, E., 1989. The role of sea ice and other freshwater in the Arctic circulation. J. Geophys. Res. 94, 14485-14498.

Bard, E., Rostek, F., Sonzogni, C., 1997. Interhemispheric synchrony of the last deglaciation inferred from alkenone palaeothermometry. Nature 385, 707-710.

Bauch, H.A., 1992. Test size variation of planktic foraminifers 
as response to climatic changes. International Conference on Paleoceanography (ICP 4). GEOMAR Report 15, 56.

Bauch, H.A., 1993. Planktische Foraminiferen im Europäischen Nordmeer — ihre Bedeutung für die paläozeanographische Interpretation während der letzten 600,000 Jahre. Report SFB 313 Kiel Univ. 40, 1-108.

Bauch, H.A., 1994. Significance of variability in Turborotalita quinqueloba (Natland) test size and abundance for paleoceanographic interpretations in the Norwegian-Greenland Sea. Mar. Geol. 121, 129-141.

Bauch, H.A., 1996. Monitoring Termination II at high latitude: Anomalies in the planktic foraminiferal record. Mar. Geol. 131, 89-102.

Bauch, H.A., 1997. Paleoceanography of the N. Atlantic Ocean $\left(68^{\circ}-78^{\circ} \mathrm{N}\right)$ during the past $450 \mathrm{ky}$ deduced from planktic foraminiferal assemblages and stable isotopes. In: Hass, H.C., Kaminski, M.A. (Eds.), Contributions to the Micropaleontology and Paleoceanography of the Northern North Atlantic. Grzybrowski Found. Spec. Publ. 5, 83-100.

Bauch, H.A., Weinelt, M.S., 1997. Surface water changes in the Norwegian Sea during last deglacial and Holocene times. Quat. Sci. Rev. 16 (10), 1115-1124.

Bauch, H.A., Erlenkeuser, H., Grootes, P.M., Jouzel, J., 1996. Implications of stratigraphic and paleoclimatic records of the last interglaciation from the Nordic seas. Quat. Res. 46, 260269.

Bauch, D., Carstens, J., Wefer, G., 1997. Oxygen isotope composition of living Neogloboquadrina pachyderma (sin.) in the Arctic Ocean. Earth Planet. Sci. Lett. 146, 47-58.

Baumann, M., 1990. Coccoliths in sediments of the eastern Arctic Basin. In: Bleil, U., Thiede, J. (Eds.), Geological History of the Polar Oceans: Arctic versus Antarctic. Kluwer, Norwell, pp. 437-445.

Baumann, K.-H., Lackschewitz, K.S., Erlenkeuser, H., Henrich, R., Jünger, B., 1993. Late Quaternary calcium carbonate sedimentation and terrigenous input along the east Greenland continental margin. Mar. Geol. 114, 13-36.

Baumann, K.H., Lackschewitz, K.S., Mangerud, J., Spielhagen, R.F., Wolf-Welling, T.C.W., Henrich, R., Kassens, H., 1995. Reflections of Scandinavian ice sheet fluctuations in Norwegian sea sediments during the past 150,000 years. Quat. Res. 43, 185-197.

Bé, A.W., Tolderlund, D.S., 1971. Distribution and ecology of living planktonic foraminifera in surface waters of the Atlantic and Indian Oceans. In: Funnel,B.M., Riedel,W.R. (Eds.), The Micropaleontology of the Oceans. Cambridge University Press, Cambridge, pp. 105-149.

Belanger, P.E., 1982. Paleo-oceanography of the NorwegianSea during the past 130,000 years: Coccolithophorid and foraminiferal data. Boreas 11, 29-36.

Birgisdottir, L., 1990. Die paläo-ozeanographische Entwicklung der Island See in den letzten 550,000 Jahren. Report SFB 313 Kiel Univ. 34, 1-112.

Bleil, U., Gard, G., 1989. Chronology and correlation of Quaternary magnetostratigraphy and nannofossil biostratigraphy in Norwegian-Greenland Sea sediments. Geol. Rundsch. 78, $1173-1187$.
Broecker, W.S., Denton, G.H., 1989. The role of oceanatmosphere reorganizations in glacial cycles. Geochim. Cosmochim. Acta 53, 2465-2501.

Bodén, P., Backman, J., 1996. A laminated sediment sequence from the northern North Atlantic and its climatic record. Geology 24, 507-510.

Carstens, J., 1991. Verteilung planktischer Foraminiferen in der Wassersäule. In: Thiede, J., Hempel, G. (Eds.), The Expedition ARKTIS-VII/1 of RV Polarstern in 1990. Reports Polar Res. $80,60-62$.

Carstens, J., Wefer, G., 1992. Recent distribution of planktonic foraminifera in the Nansen Basin, Arctic Ocean. Deep-Sea Res. 39, 507-524.

Carstens, J., Hebbeln, D., Wefer, G., 1997. Distribution of planktic foraminifera at the ice margin. Mar. Micropaleontol. 29, 257-269.

CLIMAP, 1981. Seasonal reconstructions of the earth's surface at the last glacial maximum. Geological Society America, Boulder CO, Chart Series MC-36.

CLIMAP (Project Members), 1984. The last interglacial ocean. Quat. Res. 21, 123-224.

Coachman, L.K., Aagaard, K., 1988. Transport through Bering Strait: Annual and interannual variability. J. Geophys. Res. 93 (C12), 15535-15539.

COHMAP Members, 1988. Climate changes of the last 18000 years: observations and model simulations. Science 241, 1043-1052.

Conte, M.H., Eglinton, G., 1993. Alkenone and alkenoate distributions within the euphotic zone of the eastern north Atlantic: correlation with production temperature. Deep-Sea Res. 40, 1935-1961.

Cortijo, E., Duplessy, J.-C., Labeyrie, L., Leclaire, H., Duprat, J., van Weering, T.C.E., 1994. Eemian cooling in the Norwegian Sea and North Atlantic ocean preceding continental ice-sheet growth. Nature 372, 446-449.

Crowley, T.J., Kim, K.-Y., 1994. Milankovitch forcing of the last interglacial sea level. Science 265, 1566-1568.

Dickson, R., Meincke, J., Malmberg, S.-A., Lee, A., 1988. The 'Great Salinity Anomaly' in the Northern North Atlantic 1968-1982. Progr. Oceanogr. 20, 103-151.

Dietrich, G., 1969. Atlas of the hydrography of the Northern North Atlantic Ocean. Conseil International pour L'Éxploration de la Mer Service Hydrographique, Chalottenlund Slot Danemark.

Duplessy, J.C., Labeyrie, L., Blanc, P.L., 1988. Norwegian Sea Deep Water variations over the last climatic cycle: Paleooceanographical implications. In: Wanner, H., Siegenthaler, U. (Eds.), Long and Short Term Variability of Climate. Springer, New York, pp. 83-116.

Environmental Working Group, 1998. Joint U.S.-Russian atlas of the Arctic Ocean: Oceanography atlas for the summer period. NSIDC Boulder, CO, Version 1.0.

Epstein, S., Buchsbaum, R., Lowenstam, H.A., Urey, H.C., 1953. Revised carbonate-water isotopic temperature scale. Bull. Geol. Soc. Am. 65, 1315-1328.

Fahl, K., Stein, R., 1998. Biomarkers as organic-carbon-source 
and environmental indicators in the Late Quaternary Arctic Ocean: 'problems and perspectives'. Mar. Chem., in press.

Fronval, T., Jansen, E., 1996. Rapid changes in Ocean circulation and heat flux in the Nordic seas during the last interglacial period. Nature 383, 806-810.

Fronval, T., Jansen, E., 1997. Eemian and early Weichselian (140-60 ka) paleoceanography and paleoclimate in the Nordic seas with comparisons to Holocene conditions. Paleoceanography $12,443-462$.

Gard, G., Backman, J., 1990. Synthesis of Arctic and Sub-Arctic coccolith biochronology and history of North Atlantic Drift Water Influx during the last 500,000 years. In: Bleil, U., Thiede, J. (Eds.), Geological History of the Polar Oceans: Arctic versus Antarctic. Kluwer, Norwell, pp. 417-436.

Guiot, J., de Beaulieu, J.L., Chedaddi, R., David, F., Ponel, P., Reille, M., 1993. The climate in western Europe during the last glacial/interglacial cycle derived from pollen and insects remains. Palaeogeogr. Palaeoclimatol. Palaeoecol. 103, 73-93.

Haake, F.W., Pflaumann, U., 1989. Late Pleistocene foraminiferal stratigraphy on the Vøring Plateau, Norwegian Sea. Boreas 18, 343-356.

Haake, F.W., Erlenkeuser, H., Pflaumann, U., 1992. Pullenia bulloides (ORBIGNY) in sediments of the Norwegian/Greenland Sea and the Northeastern Atlantic Ocean: Paleo-oceanographic evidence. In: Studies in Benthic Foraminifera, Benthos ' 90. Conf. Proc. Benthos '90. Tokai University Press, Sendai, pp. 235-244.

Hanzlick, D., 1983. The West Spitsbergen Current: Transport, forcing and variability. $\mathrm{PhD}$ thesis, Univ. of Washington, pp. 127

Hebbeln, D., Wefer, G., 1997. Late Quaternary paleoceanography in the Fram Strait. Paleoceanography 12, 65-78.

Hemleben, C., Spindler, M., Anderson, O.R., 1989. Modern Planktonic Foraminifera. Springer, New York, pp. 363.

Henrich, R., Kassens, H., Vogelsang, E., Thiede, J., 1989. Sedimentary facies of glacial/interglacial cycles in the Norwegian Sea during the last $350 \mathrm{ka}$. Mar. Geol. 86, 283-319.

Johannessen, T., Jansen, E., Flatøy, A., Ravelo, A., 1994. The relationship between surface water masses, oceanographic fronts and paleoclimatic proxies in surface sediments of the Greenland, Iceland, Norwegian Seas. In: Zahn, R., Pedersen, T.F., Kaminski, M.A., Labeyrie, L. (Eds.), Carbon Cycling in the Glacial Ocean: constraints of the Oceans's Role in Global Change. Springer, Berlin, pp. 61-85.

Keigwin, L., Curry, W., Lehman, S., Johnsen, S., 1994. The role of the deep ocean in North Atlantic climate change between 70 and 130 kyr ago. Nature 371, 323-326.

Kellogg, T.B., 1980. Paleoclimatology and paleoceanography of the Norwegian and Greenland Seas: Glacial-interglacial contrasts. Boreas 9, 115-137.

Kellogg, T.B., 1984. Paleoclimatic significance of subpolar foraminifera in high-latitude marine sediments. Can. J. Earth Sci. 21, 189-193.

Kipp, N.G., 1976. New transfer function for estimating past sea-surface conditions from sea-bed distribution of planktonic foraminiferal assemblages in the North Atlantic. Geol. Soc. Mem. 145, 3-41.
Koç-Karpuz, N., Jansen, E., 1992. A high-resolution diatom record of the last deglaciation from the SE Norwegian Sea; documentation of rapid climatic changes. Paleoceanography 7 , 499-520.

Koç, N., Jansen, E., Haflidason, H., 1993. Paleoceanograhic reconstructions of surface ocean conditions in the Greenland, Iceland and Norwegian Seas through the last $14 \mathrm{ka}$ based on diatoms. Quat. Sci. Rev. 12, 115-140.

Köhler, S.E.I., 1992. Spätquartäre paläo-ozeanographische Entwicklung des Nordpolarmeeres und Europäischen Nordmeeres anhand von Sauerstoff- und Kohlenstoff - Isotopenverhältnissen der planktischen Foraminifere Neogloboquadrina pachyderma (sin.) GEOMAR Report 13, 1-104.

Köhler, S.E.I., Spielhagen, R.F., 1990. The Enigma of Oxygen Isotope Stage 5 in the Central Fram Strait. In: Bleil, U., Thiede, J. (Eds.), Geological History of the Polar Oceans: Arctic versus Antarctic. Kluwer, Dordrecht, pp. 489-497.

Labeyrie, L.D., Duplessy, J.C., Blanc, P.L., 1987. Variations in mode of formation and temperature of oceanic deep water over the past 125,000 years. Nature $327,477-482$.

Labeyrie, L., Vidal, L., Cortijo, E., Paterne, M., Arnold, M., Duplessy, J., Vautravers, M., Labracherie, M., Duprat, J., Turon, J., Grousset, F., Van Weering, T., 1995. Surface and deep hydrology of the northern Atlantic ocean during the past 150,000 years. Philos. Trans. R. Soc. London B 348, 255-264.

Lackschewitz, K.S., 1991. Sedimentation am aktiven mittelozeanischen Kolbeinsey Rücken (N'Island) — Vulkanisch und klimatisch gesteuerte Ablagerungsprozesse im Spätquartär. GEOMAR Report 9, 1-133.

Lehman, S.J., Jones, G.A., Keigwin, L.D., Andersen, E.S., Butenko, G., Østmo, S.-R., 1991. Initiation of Fennoscandian ice-sheet retreat during the last deglaciation. Nature 349, 513-516.

Mangerud, J., Lie, S.E., Furnes, H., Kristiansen, I.L., Lømo, L., 1984. A Younger Dryas ash bed in Western Norway, and its possible correlations with tephra in cores from the Norwegian Sea and the North Atlantic. Quat. Res. 21, 85-104.

Mangerud, J., Dokken, T., Hebbeln, D., Heggen, B., Ingolfsson, O., Landvik, J., Mejdahl, V., Svendsen, J.I., 1998. Fluctuations of the Svalbard-Barents Sea ice sheet, the last 150,000 years. Quat. Sci. Rev. in press.

Martinson, D.G., Pisias, N.G., Hays, J.D., Imbrie, J., Moore, T.C., Shackleton, N.J., 1987. Age dating and the orbital theory of the Ice Ages: Development of a high-resolution 0 to 300,000 years chronostratigraphy. Quat. Res. 27, 1-29.

McManus, J., Bond, G., Broecker, W., Johnsen, S., Labeyrie, L., Higgins, S., 1994. High-resolution climate records from the North Atlantic during the last interglacial. Nature 371, 326329.

Müller, P.J., Cepek, M., Ruhland, G., Schneider, R., 1997. Alkenone and coccolithophorid species changes in late Quaternary sediments from the Walvis Ridge: implications for the alkenone paleotemperature method. Palaeogeogr. Palaeoclimatol. Palaeoecol. 135, 71-96.

Nees, S., Struck, U., 1994. The biostratigraphic and paleoceanographic significance of Siphotextularia roslhauseni 
Phleger and Parker in Norwegian-Greenland Sea sediments. J. Foraminiferal Res. 24, 233-240.

Nesje, A., Kvamme, M., 1991. Holocene glacier and climate variations in western Norway: Evidence for early Holocene glacier demise and multiple Neoglacial events. Geology 19, 610-612.

Nørgaard-Pedersen, N., 1998. Late Quaternary Arctic Ocean sediment records: surface ocean conditions and provenance of ice-rafted debris. GEOMAR Rep. 65, 1-115.

Nørgaard-Pedersen, N., Spielhagen, R.F., Thiede, J., Kassens, H., 1998. Central Arctic surface ocean environment during the past 80,000 years. Paleoceanography 13 (2), 193-204.

Prahl, F.G., Wakeham, S.G., 1987. Calibration of unsaturation pattern in long-chain ketone composition for paleotemperature assessment. Nature 320, 367-369.

Rahmstorf, S., 1995. Bifurcations of the Atlantic thermohaline circulation in response to changes in the hydrological cycle. Nature 378, 145-149.

Rosell-Melé, A., Eglinton, G., Pflaumann, U., Sarnthein, M., 1995. Atlantic core-top calibration of $U \frac{K^{\prime}}{37}$ index as a sea-surface paleotemperature indicator. Geochim. Cosmochim. Acta 59, 3099-3107.

Ruddiman, W.F., Shackleton, N.J., McIntyre, A., 1986. North Atlantic sea-surface temperatures for the last 1.1 million years. In: Summerhayes, C.P., Shackleton, N.J. (Eds.), North Atlantic Paleoceanography. Geol. Soc. Spec. Publ. 21, 155-173.

Rudels, B., 1995. The thermohaline circulation of the Arctic and the Greenland seas. Philos. Trans. R. Soc. London 352, 1-13.

Samtleben, C., Schäfer, P., Andruleit, H., Baumann, A., Baumannn, K.-H., Kohly, A., Mathiessen, J., Schröder-Ritzrau, A., 1995. Plankton in the Norwegian-Greenland Sea: from living communities to sediment assemblages — an actualistic approach. Geol. Rundsch. 84, 108-136.

Sarnthein, M., Jansen, E., Weinelt, M.S., Arnold, M., Duplessy, J.-C., Erlenkeuser, H., Flatøy, A., Johannessen, G., Johannessen, T., Jung, S., Koç, N., Labeyrie, L., Maslin, M., Pflaumann, U., Schulz, H., 1995. Variations in Atlantic surface ocean paleoceanography, $50^{\circ}-80^{\circ} \mathrm{N}$ : A time-slice record of the last 30,000 years. Paleoceanography 10, 1063-1094.

Schrag, D.P., Hampt, G., Murray, D.W., 1996. Pore fluid constraints on the temperature and oxygen isotopic composition of the glacial ocean. Science 272, 1930-1932.

Sejrup, H.P., Larsen, E., 1991. Eemian-Early Weichselian N-S temperature gradients; North Atlantic-NW Europe. Quat. Int. 10/12, 161-166.

Shackleton, N.J., 1987. Oxygen isotopes, ice volume and sea level. Quat. Sci. Rev. 6, 183-190.

Sikes, E.L., Volkman, J.K., 1993. Calibration of alkenones unsaturation ratios $\left(U \frac{K^{\prime}}{37}\right)$ for paleotemperature estimation in cold polar waters. Geochim. Cosmochim. Acta 57, 1883-1889.

Spielhagen, R.F., Bonani, G., Eisenhauer, A., Frank, M., Frederichs, T., Kassens, H., Kubik, P.W., Mangini, A., NørgaardPedersen, N., Nowaczyk, N.R., Schäper, S., Stein, R., Thiede, J., Tiedemann, R., Wahsner, M., 1997. Arctic Ocean evidence for late Quaternary initiation of northern Eurasian ice sheets. Geology 25, 738-786.

Stein, R., Nam, S.-I., Schubert, C., Vogt, C., Fütterer, D., Heinemeier, J., 1994. The last deglaciation event in the eastern Central Arctic Ocean. Science 264, 692-696.

Struck, U., 1995. Stepwise post-glacial migration of benthic foraminifera into the abyssal NE Norwegian Sea. Mar. Micropaleontol. 26, 207-213.

Stute, M., Forster, M., Frischkorn, H., Serejo, A., Clark, J.F., Schlosser, P., Broecker, W.S., Bonani, G., 1995. Cooling of tropical Brazil $\left(5^{\circ} \mathrm{C}\right)$ during the last glacial maximum. Science 269, 379-383.

Swift, J., 1986. The Arctic Waters. In: Hurdle, B. (Ed.), The Nordic Seas. Springer, New York, pp. 129-151.

Velichko, A.A., Barash, M.S., Grichuk, M.P., Gurtoyova, Y.Y., Zelikson, E.M., 1984. Climate of the northern hemisphere in the last interglacial (Mikulino). Russ. Acad. Sci. USSR, Ser. Geogr. N1, 30-45.

Villanueva, J., Grimalt, J.O., Vidal, L., Cortijo, E., Labeyrie, L., 1998. Assessment of SST variations in the North Atlantic Ocean using the Uk37 index. Geochim. Cosmochim. Acta, in press.

Vogelsang, E., 1990. Paläo-Ozeanographie des Europäischen Nordmeeres anhand stabiler Kohlenstoff- und Sauerstoffisotope. Report SFB 313 Kiel Univ. 23, 1-136.

Williams, K.M., Andrews, J.T., Weiner, N.J., Mudie, P.J., 1995. Late Quaternary paleoceanography of the mid- to outer continental shelf, East Greenland. Arct. Antarct. Res. 27, 352363.

Woillard, G.M., 1978. Grande Pile peat bog: A continuous pollen record for the last 140,000 years. Quat. Res. 9, 1-21. 